7.

Derecho penal 

Revista de Derecho

de la Pontificia Universidad Católica de Valparaíso

XXXVI (Valparaíso, Chile, 2011, $1^{\text {er }}$ Semestre)

[pp. 359-395]

\title{
ESTRUCTURA TÍPICA COMÚN DE LOS DELITOS DE HURTO Y ROBO*
}

["Typical Common Structure of Robbery and Burglary"]

\author{
Guillermo Oliver Calderón** \\ Pontificia Universidad Católica de Valparaíso
}

\begin{abstract}
RESUMEN
Los delitos de hurto y robo poseen una estructura típica común. En relación con la conducta, ésta debe consistir en una apropiación, que debe ser ejecutada sin voluntad del dueño de la cosa apropiada y con ánimo de lucro. En relación con el objeto material de la acción, debe tratarse de una cosa corporal, mueble, ajena, susceptible de apropiación y de apreciación pecuniaria. En este trabajo se examinan ciertas particularidades de cada una de estas exigencias.

Palabras Clave

Hurto - Robo - Sustracción - Ánimo

de lucro - Cosa corporal mueble ajena.
\end{abstract}

\begin{abstract}
The crimes of robbery and burglary have a typical common structure. Regarding behavior, this must consist of embezzlement without the consent of the owner of the embezzled thing, and with the purpose of animus lucrandi. Regarding the material object of the action, this must be a physical thing, movable, belonging to other people, sensitive to embezzlement and of pecuniary appraisal. This article examines certain features of each of these requirements.

KEYWORDS

Robbery - Burglary - Theft - Animus Lucrandi-Movable physical thing belonging to other people.
\end{abstract}

[RECIBIDo el 19 de diciembre de 2010 y aCEPTADo el 3 de mayo de 2011].

* Este trabajo fue realizado en el marco del proyecto de investigación FONDECYT No 1070421: "Formulación de una teoría general de los delitos contra el patrimonio con base en el derecho chileno: estudio dogmático y crítico", en el que su autor se desempeñó como investigador principal.

${ }^{* *}$ Doctor en Derecho por la Universidad de Barcelona; profesor en la Facultad de Derecho de la Pontificia Universidad Católica de Valparaíso. Dirección postal: Avenida Brasil 2950, Valparaíso, Chile. Dirección electrónica: guillermo.oliver@ucv.cl 


\section{INTRODUCCIÓN}

El artículo 432 CP. establece que quien sin la voluntad del dueño y con ánimo de lucro, se apropia cosa mueble ajena usando de violencia o intimidación en las personas o de fuerza en las cosas, comete robo; si faltan la violencia, la intimidación y la fuerza, el delito se califica de hurto. El análisis de esta disposición permite concluir que los delitos de hurto y robo poseen una estructura típica común, tanto en lo que dice relación con el comportamiento prohibido, como en lo que respecta al objeto material sobre el que recae. El objetivo de este trabajo es examinar cada uno de estos elementos.

\section{Conducta}

Un breve examen de derecho comparado pone de relieve la existencia de distintas opciones legislativas al momento de describir la conducta prohibida en la regulación del hurto y del robo. A veces, se utiliza la expresión "apoderarse". Así sucede, por ejemplo, en los Códigos Penales argentino (artículo 162), boliviano (artículo 326), peruano (artículo 185) ${ }^{1}$, colombiano (artículo 239), costarricense (artículo 208), nicaragüense (artículo 263), mexicano (artículo 367) e italiano (artículo 624) ${ }^{2}$. En ocasiones, se usa la voz "tomar". Es el caso, verbigracia, de los Códigos Penales hondureño (artículo 223) ${ }^{3}$ y español (artículo 234)4. Otras veces, se utiliza la expresión "sustraer". Así ocurre, por ejemplo, en los Códigos Penales brasileño (artículo 155), portugués (artículo 203), francés (artículo 311-1) y suizo (artículo 139). También se usa el término "quitar", como se observa, verbigracia, en el Código Penal alemán (parágrafo 242).

\section{Sentido y alcance del término "apropiarse".}

El legislador chileno ha decidido aludir al comportamiento punible con la voz apropiarse. Según nuestra opinión, esta manera de describir la

${ }^{1}$ Efectivamente, el Código peruano describe la conducta como apoderarse, pero también se refiere al modo de ejecutarla, utilizando la frase "sustrayéndolo (un bien mueble) del lugar donde se encuentra".

${ }^{2} \mathrm{Al}$ igual que lo que sucede en el Código Penal peruano, la citada disposición del Código italiano describe el comportamiento como "apoderarse", pero cuando alude al modo de ejecución de dicha conducta utiliza la voz sustraer.

${ }^{3} \mathrm{Al}$ aludir al hurto, el Código hondureño usa la voz "tomar", pero al referirse al robo utiliza la expresión "apoderarse" (artículo 217).

${ }^{4} \mathrm{Si}$ bien es cierto que en el artículo 234, el tratar sobre el hurto, el Código español describe el comportamiento como tomar, al aludir a ciertas formas agravadas de dicho delito utiliza la voz "sustraer" (artículo 235). Y al regular el delito de robo, usa la expresión "apoderarse" (artículo 237). 
conducta, al igual que la que usa la voz apoderarse, desde el punto de vista de una mejor protección del bien jurídico, resulta preferible a aquellas que utilizan las voces "sustraer" o "tomar", ya que estas últimas expresiones parecen algo restrictivas, al aludir a un concreto modo de ejecución. Al exigirse una apropiación o apoderamiento de la cosa, o sea, hacerla propia un individuo o sujetarla a su poder -lo cual no parece que pueda determinarse con prescindencia total de criterios normativos-, es indiferente el modo en que esto tenga lugar. Por ejemplo, si al patio de la casa de una persona, que se encuentra con el portón abierto, llegara imprevistamente un animal perteneciente a un vecino, y el dueño de la casa cerrara el portón para que el animal no pueda salir nunca más, podría afirmarse que ha habido apropiación o apoderamiento, pero difícilmente podría sostenerse que el animal ha sido sustraído o tomado. En otras palabras, en Chile, el hurto parece ser un delito de medios indeterminados.

Sin embargo, a pesar de que el legislador no ha determinado el modo en que debe tener lugar la apropiación, una interpretación sistemática de las disposiciones relativas al hurto permite concluir que ella debe verificarse a través de una sustracción de la cosa objeto material del delito. En efecto, el artículo $448 \mathrm{CP}$. contempla el denominado "hurto de hallazgo", que consiste, en términos generales, en encontrarse especies muebles al parecer perdidas o abandonadas y no entregarlas a su dueño o a la autoridad. En estos casos, la cosa objeto del delito se encuentra fuera de la custodia de su titular. Por lo tanto, resulta forzoso entender que para que tenga lugar la apropiación en un hurto o en un robo, es necesario que la cosa aún se encuentre bajo la esfera de custodia o resguardo de su titular, esfera desde la cual debe ser sustraída. En otras palabras, de modo similar a lo que explícitamente se declara en los Códigos Penales peruano e italiano, conforme al Código Penal chileno, en el hurto y en el robo la cosa debe ser apropiada mediante su sustracción.

Desde luego, el hecho de que el legislador chileno exija una apropiación no significa que quien comete hurto o robo se convierte en propietario de la cosa hurtada o robada, ya que los delitos no constituyen modos de adquirir el dominio. El dueño de la cosa hurtada o robada no pierde su calidad de tal; su derecho de dominio se mantiene incólume. Lo que sucede es que, de hecho, el delincuente se arroga las facultades del dueño, quien se ve privado de la cosas. En consecuencia, la conducta consiste en la realización de cualquier forma de sustracción que implique apoderarse de la cosa. Lo más frecuente será la

${ }^{5}$ Garrido Montt, Mario, Derecho penal. Parte especial (4a edición, Santiago, Editorial Jurídica de Chile, 2008), IV, p. 159. 
aprehensión manual de la misma, pero nada obsta a la utilización de otras formas, tales como perros amaestrados, trampas ${ }^{6}$, imanes potentes, etc.

Sin embargo, si bien esto es cierto desde el punto de vista de la parte objetiva de la estructura típica común del hurto y del robo, también lo es que no resulta suficiente para realizar el comportamiento típico. La apropiación exigida por la ley supone algo más que el simple apoderamiento mediante sustracción. En efecto, para realizar el tipo es necesario que la sustracción esté acompañada del denominado animus rem sibi habendi, animus domini o ánimo de señor y dueño. Este ánimo, que junto con otro más (ánimo de lucro) y con el dolo integra la parte subjetiva del tipo, consiste en la intención de comportarse como dueño de la cosa sustraída ${ }^{7}$. Por lo tanto, la apropiación constituye un elemento típico complejo, que abarca dos partes: una objetiva (la sustracción) y otra subjetiva (el ánimo de señor y dueño). Apropiarse de una cosa significa, por ende, apoderarse de ella mediante su sustracción, con ánimo de señor y dueño ${ }^{8}$.

Con todo, resulta conveniente tener presente que este es el significado de la apropiación para efectos del hurto y del robo, ya que en el artículo 470 No 1 CP., que tipifica el delito de apropiación indebida, la ley utiliza el mismo verbo rector (apropiarse), a pesar de que la cosa ajena se encuentra bajo custodia previa del sujeto activo. Esto permite conceptualizar en términos más normativos la conducta de apropiación, en el sentido del hurto y del robo, por oposición al sentido que tiene en la apropiación indebida, como la ruptura de la custodia ajena y la constitución de una nueva custodia sobre la cosa, con ánimo de señor y dueño?

\section{Exclusión del mero uso de una cosa.}

El hecho de que el legislador describa la conducta en el hurto y en el robo como apropiarse es de la mayor relevancia, ya que permite colegir que en Chile no se castiga el denominado hurto de uso. Se conoce con este nombre

${ }^{6}$ Labatut Glena, Gustavo, Derecho penal (7a edición actualizada por Julio Zenteno Vargas, Santiago, Editorial Jurídica de Chile, 2000, II, p. 196.

${ }^{7}$ Por todos: Politoff, Sergio - Matus, Jean Pierre - Ramírez, María Cecilia, Lecciones de Derecho penal chileno. Parte especial (2 ${ }^{a}$ edición, Santiago, Editorial Jurídica de Chile, 2005), p. 306.

${ }^{8}$ Cfr. Labatut Glena, Derecho penal, cit. (n. 6), II, pp. 195 s.; Etcheberry, Alfredo, Derecho penal. Parte especial ( $3^{a}$ edición, Santiago, Editorial Jurídica de Chile, 1998), III, p. 296; Politoff - Matus - Ramírez, Lecciones, cit. (n. 7), p. 306; Bullemore, Vivian - Mackinnon, John, Curso de Derecho penal. Parte especial (2a edición, Santiago, LexisNexis, 2007), IV, p. 14.

${ }^{9}$ Bascuñán Rodríguez, Antonio, Delitos contra intereses instrumentales, en Revista de Derecho de la Universidad Adolfo Ibáñez (Comentario de la jurisprudencia del año 2003 de la Corte Suprema y del Tribunal Constitucional), 1 (2004), p. 299. 
el comportamiento consistente en apoderarse de una cosa sin ánimo de señor y dueño, para usarla y luego restituirla a su propietario ${ }^{10}$. Se le ha definido también como la apropiación de una cosa ajena sin ánimo de señor y dueño ${ }^{11}$, pero como se comprenderá, si dicho ánimo no estuviera presente, mal podría hablarse de apropiación ${ }^{12}$.

Durante algún tiempo se sostuvo que era posible sancionar el hurto de uso. Del Río afirmaba esto, argumentando que la ley no distinguía clases de hurto y que el ánimo de devolución no impedía entender configurado el delito ${ }^{13}$. Algunos fallos antiguos así lo declararon ${ }^{14}$. No obstante, en la actualidad, prácticamente no se tienen dudas acerca de la atipicidad del hurto de uso, ya que la conducta descrita en el artículo 432 CP. - la apropiación- exige, además del apoderamiento mediante sustracción, el animus rem sibi habendi ${ }^{15}$. Sólo podría tener cabida esta figura si el tipo describiera el comportamiento como apoderarse ${ }^{16}$, sustraer o tomar, pero no es el caso ${ }^{17}$. Los tribunales suelen sostener que se trata de una conducta atípica ${ }^{18}$.

Por nuestra parte, podemos agregar, como otro argumento a favor de la misma idea, que la pena en el delito de hurto no se hace depender del valor del uso de la cosa, ni del perjuicio causado al sujeto pasivo, así como tampoco del provecho efectivo alcanzado por el autor, sino del valor de la cosa hurtada

${ }^{10}$ Garrido Montt, Derecho penal, cit. (n. 5), IV, p. 172.

${ }^{11}$ Así, Etcheberry, Derecho penal, cit. (n. 8), III, p. 306.

${ }^{12}$ Véase la crítica en tal sentido, de Bullemore - MaCkinnon, Curso, cit. (n. 8), IV: Parte especial, pp. $24 \mathrm{~s}$.

${ }^{13}$ Del Río, Raimundo, Derecho Penal (Santiago, Editorial Nascimento, 1935), III, p. 426.

${ }^{14}$ Por ejemplo, sentencia de la Corte de Apelaciones de Talca, en Gaceta de Tribunales, 106 (1927, primer semestre), p. 454, citado por SCHEPELER VÁsQUEZ, Enrique, El delito de hurto. Estudio de doctrina, de jurisprudencia y de legislación comparada (Santiago, 1939), p. 18.

${ }^{15}$ Por todos: KÜNSEmÜller, Carlos, Hurto-hurto de uso. Jurisprudencia comentada, en Temas de Derecho. Revista de la Universidad Gabriela Mistral, año XIII, 1-2 (1998), pp. 191-201. Véase también: García Carvajal, Edmundo, El hurto de uso (Santiago, Editorial Universitaria, 1962), p. 71; SCHEPELER VÁsQuez, Enrique, Hurto de uso. Comentario a sentencia, en Revista de Ciencias Penales, $2^{\mathrm{a}}$ época, 10 (abrilseptiembre 1948) 2-3, pp. 200-204.

${ }^{16}$ A pesar de que en el Código Penal argentino, el tipo de hurto (artículo 162) emplea el verbo rector "apoderarse", un sector doctrinal de dicho país sostiene igualmente la atipicidad del hurto de uso. Cfr. Ramos Mejías, Enrique, El hurto de uso, en EL mismo, Estudios de Derecho penal (Buenos Aires, Editorial Ideas, 1947), pp. 143-146.

${ }^{17}$ Etcheberry, Derecho penal, cit. (n. 8), III, p. 306.

${ }^{18}$ Entre otras, véase la sentencia de la Corte de Apelaciones de San Miguel, de 2 de octubre de 1997, emitida en causa rol No 1955-1997. 
(artículo 446 CP.), lo que parece sugerir que el denominado hurto de uso no se castiga en Chile ${ }^{19}$.

A mayor abundamiento, un reconocimiento de esta idea se encuentra en el texto del "Anteproyecto de Nuevo Código Penal" chileno, cuyo artículo 151 castiga la sustracción de un vehículo motorizado ajeno sin ánimo de apropiárselo, siempre que no haya mediado violencia ni intimidación. Esta previsión demuestra que para poder sancionar el hurto de uso se necesita una modificación legal.

La misma idea ha llevado a reformar muchos códigos extranjeros, que en la actualidad contemplan disposiciones especiales que tipifican el hurto de uso. Así sucede, por ejemplo, en los Códigos Penales boliviano (artículo 328 ), colombiano (artículo $\left.242 \mathrm{~N}^{\circ} 1\right)^{20}$, costarricense (artículo 211), salvadoreño (artículo 210), guatemalteco (artículo 248), mexicano (artículo 380), nicaragüense (artículo 265), paraguayo (artículo 170), peruano (artículo 187), uruguayo (artículo $342 \mathrm{~N}^{\circ} 1$ ), italiano (artículo $626 \mathrm{~N}^{\circ} 1$ ), alemán (parágrafo 248 b) y español (artículo 244). En algunos de estos códigos se reserva el castigo sólo para los casos en que el objeto material del delito es un vehículo, pero siempre con una pena más baja que la correspondiente al hurto común.

Como se comprenderá, así como es posible hablar de un hurto de uso, también lo es referirse a un "robo de uso". Esta figura consiste, al igual que la anterior, en un apoderamiento o en una sustracción de una cosa ajena, sin ánimo de señor y dueño, o sea, sólo para usarla y luego restituirla, pero se diferencia en que para ello se emplea violencia o intimidación en las personas o fuerza en las cosas.

Por las mismas razones señaladas con anterioridad, es posible concluir que el robo de uso no se sanciona como tal en Chile, sin perjuicio de los delitos a que den lugar el ejercicio de violencia o intimidación en las personas o el empleo de fuerza en las cosas. Pero lo que no es posible dudar es que dicho comportamiento puede tener lugar. Un sector de la doctrina lo niega, argumentando que la violencia, la intimidación y la fuerza son reveladoras del

${ }^{19}$ En este mismo sentido, pero aludiendo a la atipicidad del hurto de uso de objetos distintos de vehículos de motor en el Código Penal español, véase la argumentación de Rodríguez Ramos, Luis, El hurto de uso en general, en Cuadernos de Política Criminal, 1 (1977), p. 139.

${ }^{20}$ No obstante, incluso antes de la incorporación en la legislación penal colombiana de una figura destinada a sancionar el hurto de uso, la doctrina y la jurisprudencia de dicho país entendían que tal comportamiento igualmente se castigaba, porque estaba comprendido por la figura básica de hurto. Así, Mantilla Jacome, Rodolfo, Hurto de uso, en Derecho Penal y Criminología. Revista del Instituto de Ciencias Penales y Criminológicas de la Universidad Externado de Colombia, 7 (1984) 23, p. 186. 
animus rem sibi habend $i^{21}$. Según nuestra opinión, es perfectamente posible que el apoderamiento o la sustracción tengan lugar sin ánimo de señor y dueño, a pesar de que se ejerza violencia, intimidación o fuerza. Piénsese, por ejemplo, en el sujeto que ingresa por la ventana a un lugar habitado -forma de fuerza en las cosas prevista en el artículo 440 No 1 CP.- para sustraer una impresora y utilizarla en su hogar por unas horas y devolverla más tarde. Por lo demás, la posibilidad conceptual de esta figura explica que en algunos países no sólo esté tipificado el hurto de uso, sino también el robo de uso. Así sucede, entre otros, en los Códigos Penales guatemalteco (artículo 253) y español (artículo 244 apartados 2 y 4 ).

Hemos dicho que el hurto de uso, al igual que el robo de uso, en Chile no se sanciona. Sin embargo, es nuestra opinión que para ello es necesario que el uso sea inmediatamente posterior a la sustracción (que la cosa sustraída no sea guardada para una ocasión futura), que éste sea sólo temporal (que la cosa se utilice por un breve tiempo), que no implique la destrucción de la cosa (de lo contrario, habría un delito de daños) y que tras el uso la cosa sea inmediatamente devuelta a su titular (que la cosa usada no sea guardada para utilizarla nuevamente ${ }^{22}$. Por mucho que el sujeto reconozca en todo momento dominio ajeno, si sustrae la cosa para usarla durante un tiempo prolongado, por ejemplo, diez años, parece razonable afirmar que comete hurto o robo ${ }^{23}$. Por algo algunas legislaciones que tipifican el hurto de uso exigen expresamente, para su aplicación, que la cosa sea devuelta en un breve plazo. Es lo que sucede, verbigracia, en el Código Penal español, cuyo artículo 244, que tipifica el robo y hurto de uso de vehículos, exige que la cosa sea restituida dentro de un plazo de cuarenta y ocho horas, vencido el cual el hecho es castigado como hurto o robo, según corresponda ${ }^{24}$. En el

${ }^{21}$ Así, Labatut Glena, Derecho Penal, cit. (n. 6), II, p. 196; Politoff - Matus - Ramírez, Lecciones, cit. (n. 7), p. 308.

${ }^{22}$ Labatut Glena, Derecho Penal, cit. (n. 6), II, p. 196; Politoff - Matus Ramírez, Lecciones, cit. (n. 7), p. 196. Véase también Etcheberry, Derecho penal, cit. (n. 8), III, p. 306, quien destaca que en el hurto de uso la sustracción de la cosa es "para servirse temporalmente de ella" (el destacado es nuestro).

${ }^{23}$ Así, Bullemore - Mackinnon, Curso, cit. (n. 8), IV: Parte especial, p. 25.

${ }^{24} \mathrm{La}$ devolución de la cosa dentro de este plazo permite presumir la ausencia del animus domini. Así, De Vicente Martínez, Rosario, El delito de robo y burto de uso de vehículos (Valencia, Tirant lo Blanch, 2007), p. 82. Con todo, un sector de la doctrina española critica el señalamiento de este plazo, afirmando que en este delito influye mucho el azar y que lo normal no es que el sujeto devuelva el vehículo, sino que lo abandone, por lo que a pesar de que no lo haya usado más de cuarenta y ocho horas, igualmente se le imponga una pena más grave a título de hurto o de robo. Cfr. SERRAno Gómez, Alfonso - Serrano Maíllo, Alfonso, Derecho penal. Parte especial, cit. (n. 24), p. 395. 
fondo, si un sujeto sustrae una cosa ajena para usarla diez años, por mucho que reconozca el dominio ajeno y vocifere que ella pertenece al afectado y que no se la quiere apropiar, ya lo habrá hecho ${ }^{25}$.

Todo cuanto llevamos dicho acerca del hurto de uso se refiere sólo a una de las dos clases de dicha figura que la doctrina reconoce: aquella en la que el sujeto sustrae una cosa ajena para usarla y luego devolverla. Esto es a lo que normalmente se refieren los autores cuando emplean dicha denominación. Pero también se utiliza esa terminología, aunque en forma aislada y ya casi abandonada, para aludir a un comportamiento distinto: el de usar indebidamente una cosa ajena que ya se poseía, conducta que, al parecer, corresponde al sentido que tenía el llamado furtum usus en el Derecho romano ${ }^{26}$. Para hacer referencia a este comportamiento se emplean también las denominaciones "hurto por exceso de uso", "por abuso de uso", "de uso ilegítimo", "no autorizado", o "usurpación de uso" ${ }^{27}$. Como se comprenderá, esta clase de conducta constituye en Chile una modalidad del delito de apropiación indebida, previsto en el artículo $470 \mathrm{~N}^{\circ} 1 \mathrm{CP}^{28}$. Esta disposición sanciona a los que "en perjuicio de otro se apropiaren o distrajeren dinero, efectos o cualquiera otra cosa mueble que hubieren recibido en depósito, comisión o administración, o por otro título que produzca obligación de entregarla o devolverla". El comportamiento de distraer corresponde precisamente a esta segunda forma de entender la expresión hurto de uso, ya que significa, en términos generales, dar a una cosa un uso o destino diferentes de los que le están asignados ${ }^{29}$. En consecuencia, es a propósito de un estudio del delito de apropiación indebida donde debería examinarse esta conducta.

\section{Requisitos de la apropiación.}

De conformidad con lo dispuesto por el artículo 432 CP., dos son los requisitos que la apropiación debe cumplir para configurar el hurto o el robo:

${ }^{25}$ Véase Aguilar Aranela, Cristian, Delitos patrimoniales (Santiago, Editorial Metropolitana, 2008), p. 49, quien afirma que el hurto de uso no se sanciona, porque no concurre el ánimo de apropiación, "salvo que el uso sea indefinido".

${ }^{26}$ Zugaldía Espinar, José Miguel, Los delitos contra la propiedad y el patrimonio (Madrid, Akal, 1988), pp. 66-69. En el mismo sentido, Ramos Mejías, El hurto de uso, cit. (n. 19), p. 139.

${ }^{27}$ Véase: SCHepeler VÁsquez, El delito de hurto, cit. (n. 14), p. 17.

${ }^{28}$ Ibíd.

${ }^{29}$ Cfr. Etcheberry, Derecho penal, cit. (n. 8), III, p. 425. Sin embargo, existe una muy bien fundada opinión doctrinal que plantea que sólo dan lugar al delito de apropiación indebida aquellas distracciones que hacen absolutamente imposible el cumplimiento de la obligación de entregar o devolver. Entre otros, véase Soto PiÑEIro, Miguel, La apropiación indebida (Acción, autor y resultado típico) (Santiago, Editorial Jurídica ConoSur, 1994), passim. 
en la parte objetiva del tipo, que la acción se realice sin la voluntad del dueño; en la parte subjetiva, que se ejecute con ánimo de lucro. A continuación, examinaremos cada uno de estos requisitos.

a) Ausencia de voluntad del dueño. Como hemos visto, el citado artículo 432 exige que la apropiación de la cosa se realice sin la voluntad de su dueño. Este es un requisito que no todas las legislaciones penales extranjeras contemplan. La verdad sea dicha, son pocas las que lo prevén. Entre otros, lo exigen los Códigos Penales guatemalteco (artículo 246), hondureño (artículo 223), venezolano (artículo 453) y español (artículo 234), que emplean expresiones tales como "sin la voluntad del dueño", "sin el consentimiento del dueño" y "sin la debida autorización".

Es explicable que se trate de un requisito que en general no sea exigido en el derecho comparado, porque resulta algo inútil, al tratarse de una innecesaria referencia a la antijuridicidad de la conducta ${ }^{30}$. En efecto, aun suprimiendo dicha exigencia típica, siempre será posible estimar que no hay delito cuando existe voluntad del dueño de la cosa, por concurrir la causa de justificación de consentimiento del ofendido.

Además, el Código Penal chileno presenta una curiosidad en este punto, ya que mientras, por una parte, el citado artículo 432 exige que la apropiación tenga lugar "sin la voluntad de su dueño", el epígrafe del párrafo en el que se contiene dicha disposición reza así: De la apropiación de las cosas muebles ajenas contra la voluntad de su dueño. La discordancia es evidente. No es lo mismo obrar sin la voluntad del propietario, que contra su voluntad. En el primer caso, no es necesario que el dueño se entere de la acción que pretende realizar el sujeto activo. En el segundo, sí lo es, ya que sólo así puede manifestar una voluntad contraria.

Esta contradicción ha originado en la doctrina una discusión. Hay quienes sostienen que la expresión "contra" es aplicable al robo, en tanto que la voz "sin" lo es al hurto ${ }^{31}$. La verdad es que esta opinión se encuentra prácticamente abandonada, porque no parece justificada. Conforme a los términos del artículo 432, la voz "sin" es aplicable tanto al hurto como al robo. La razón de la discordancia es histórica. En el proyecto de redacción de la regulación del robo y del hurto, que en la sesión $N^{\circ} 91$ de la comisión

${ }^{30}$ En este sentido, Blasco Fernández de Moreda, Francisco, Hurto, en Enciclopedia Jurídica Ameba (Buenos Aires, Editorial Bibliográfica Argentina, 1961), XIV, p. 664, aludiendo a códigos latinoamericanos que contemplan exigencias de esta clase u otras más genéricas, tales como el obrar “ilegítimamente”. En el artículo 148 del “Anteproyecto de Código Penal” chileno, que trata sobre el hurto, se sigue contemplando la referencia a la falta de voluntad del dueño.

${ }^{31}$ Así, Labatut Glena, Derecho penal, cit. (n. 6), II, p. 199; Del Río, Derecho penal, cit. (n. 13), III, p. 430. 
redactora del Código Penal, de 5 de junio de 1872, presentó don Manuel Rengifo, tanto en el epígrafe del primer párrafo como en el artículo 419 del proyecto -el antecedente del actual artículo 432-, se utilizaba la frase "contra la voluntad". Dicha frase fue sustituida en la sesión siguiente, de 7 de junio de 1872, por la de "sin la voluntad de su dueño", porque con la anterior redacción "podrían no comprenderse los casos de hurtos hechos sin noticia del dueño de la cosa hurtada"32. Nosotros agregamos que tampoco se podrían entender incluidos los casos de robos efectuados sin noticia del dueño de la cosa robada. Sin embargo, la comisión hizo el cambio sólo en el artículo, olvidando realizar la misma sustitución en el epígrafe del párrafo. En consecuencia, la subsistencia de la voz "contra" obedece sólo a una omisión. Lo que la ley pretende es sancionar la apropiación de cosa ajena efectuada sin voluntad de su dueño, haya tenido éste noticia del hecho o no ${ }^{33}$.

De lo dicho se desprende que cuando la apropiación de la cosa ajena se realiza con la voluntad de su dueño, no hay delito. Si bien esto es claro, no existe unanimidad en la doctrina nacional acerca de cuál es el concreto elemento del delito que en tal caso no concurre. Mientras unos afirman que falta la antijuridicidad del comportamiento ${ }^{34}$, otros sostienen que falta la tipicidad de la conducta ${ }^{35}$. A nuestro juicio, se trata de una hipótesis de atipicidad. En efecto, dado que el legislador ha incorporado dentro del tipo penal la exigencia de que se obre sin la voluntad del dueño, el comportamiento apropiatorio que tiene lugar con su consentimiento no puede ser considerado típico. Esta es, por lo demás, la opinión mayoritaria en España, cuyo Código Penal contempla una exigencia idéntica a la nuestra ${ }^{36}$.

${ }^{32}$ Cfr. De Rivacoba y Rivacoba, Manuel (director), Código Penal de la República de Chile y Actas de las Sesiones de la Comisión Redactora del Código Penal chileno (Valparaíso, Edeval, 1974), p. 420.

${ }^{33}$ Etcheberry, Derecho penal, cit. (n. 8), III, pp. 303 s.; Garrido Montt, Derecho penal, cit. (n. 5), IV, p. 168; Bullemore - MaCKInnon, Curso, cit. (n. 8), IV, Parte especial, pp. 19 s.

${ }^{34}$ Así, Etcheberry, Derecho penal, cit. (n. 8), III, p. 302; Labatut Glena, Derecho penal, cit. (n. 6), II, p. 199.

${ }^{35}$ En este sentido, Garrido Montt, Derecho penal, cit. (n. 5), IV, p. 168; PoliTOFf - Matus - Ramírez, Lecciones, cit. (n. 7), p. 308; Bullemore - Mackinnon, Curso, cit. (n. 8), IV: Parte especial, p. 20.

${ }^{36}$ Cfr. García Arán, Mercedes, Delitos contra el patrimonio y contra el orden socioeconómico, en Córdoba Roda - García Arán (directores), Comentarios al Código Penal. Parte especial (Madrid, Marcial Pons, 2004), I, p. 622; Quintero OliVARES, Gonzalo, Delitos contra el patrimonio y contra el orden socioeconómico, en EL Mismo (director), Comentarios a la parte especial del Derecho penal ( 6 a edición, Pamplona, Thomson-Aranzadi, 2007), p. 594; Muñoz Conde, Francisco, Derecho penal. Parte especial (16 edición, Valencia, Tirant lo Blanch, 2007), pp. 374 s.; Queralt 
En otro orden de ideas, se ha suscitado en la doctrina una discusión acerca del alcance que debe atribuirse a la expresión "dueño". Algunos autores afirman que dicha voz debe ser entendida en sentido estricto ${ }^{37}$. Otros sostienen que se le debe dar un alcance más amplio, comprensivo también del mero tenedor ${ }^{38}$. Según nuestra opinión, para abordar este tema deben examinarse las consecuencias a que conducen una y otra opinión en las hipótesis de consentimiento antagónico ${ }^{39}$. Con esta denominación se conocen los casos en que, encontrándose la cosa en manos de un mero tenedor, un tercero se la apropia con la voluntad de éste, pero no con la del dueño, o a la inversa, lo hace con la voluntad del propietario, pero no con la del mero tenedor. Para examinar mejor este tema, analizaremos las cuatro posibles situaciones que pueden originarse a raíz de la presencia o ausencia de voluntad de dichas personas, en relación con la apropiación:

i) No existe voluntad del propietario, ni tampoco del mero tenedor: En este caso, cualquiera sea el alcance que se atribuya a la expresión "dueño", el requisito típico se cumple.

ii) Hay voluntad tanto del propietario como del mero tenedor: En esta hipótesis, cualquiera sea el sentido de la voz "dueño", la exigencia típica no se satisface.

iii) No existe voluntad del propietario, pero sí del mero tenedor: En este supuesto, la solución del problema dependerá del alcance que se asigne al término "dueño". Si se le atribuyera un sentido lato, no podría apreciarse un hurto en la apropiación que realice el tercero; si se le diera un alcance restringido, el requisito típico se consideraría cumplido ${ }^{40}$. A nuestro juicio, en este caso no es posible considerar que haya un delito de hurto, ya que la esencia de éste, como lo dijimos más arriba, está en el rompimiento de la custodia ajena y la constitución de una custodia nueva sobre la cosa, con ánimo de señor y dueño. Esto quiere decir que para que haya hurto de una cosa debe obrarse sin la voluntad de quien se encuentra custodiándola. Si el custodio consiente en que el tercero se lleve la cosa, mal podría decirse que

Jiménez, Joan, Derecho penal español. Parte especial (5a edición, Barcelona, Atelier, 2008), p. 393; SÁnchez Moreno, José, El hurto (Barcelona, Bosch, 1999), p. 14.

${ }^{37}$ En esta línea de pensamiento: GARrido Montt, Derecho penal, cit. (n. 5), IV, p. 169; SChepeler VÁsQuez, El delito de hurto, cit. (n. 14), p. 56. En la doctrina española, Queralt Jiménez, Derecho penal, cit. (n. 36), p. 393.

${ }^{38}$ Así, Politoff - Matus - Ramírez, Lecciones, cit. (n. 7), p. 308; Labatut Glena, Derecho penal, cit. (n. 6), II, p. 200. En la doctrina española, Quintero Olivares, Delitos contra el patrimonio, cit. (n. 36), p. 594.

${ }^{39}$ Tomamos esta expresión de Schepeler VÁsQuez, El delito de hurto, cit. (n. 14), p. 56.

${ }^{40}$ Esta es la opinión de Schepeler VÁsquez, El delito de hurto, cit. (n. 14), p. 57. 
este último rompe la custodia anterior; en realidad, es el propio mero tenedor quien pone fin a dicha custodia. En todo caso, esto no obsta a la posibilidad de apreciar un delito de apropiación indebida por la imposibilidad del mero tenedor de restituir la cosa a su dueño ${ }^{41}$.

iv) Hay voluntad del propietario, pero no del mero tenedor: En este caso, al igual que en el anterior, la solución del problema pasa por determinar el sentido de la voz "dueño". Si se le diera un alcance amplio, podría apreciarse un hurto; si se le atribuyera uno restringido, no se podría hacer ${ }^{42}$. Según nuestra opinión, en esta hipótesis sí puede apreciarse un hurto ${ }^{43}$, ya que como lo dijimos, para que dicho delito se configure es necesario que se obre sin la voluntad de quien se encuentra custodiando la cosa. Al no consentir el mero tenedor en que el tercero se lleve la cosa, es posible afirmar que éste rompe la custodia ajena y constituye una nueva sobre la misma. La opinión de quienes creen que en este caso no puede apreciarse un hurto no nos parece correcta, porque conduce a conclusiones absurdas. En efecto, no resulta razonable afirmar que si un tercero, con consentimiento del dueño de la cosa, la sustrae de su mero tenedor, no comete hurto, toda vez que si es el propio dueño quien la quita al mero tenedor, comete el denominado delito de hurto de posesión, contemplado en el artículo $471 \mathrm{~N}^{\circ} 1 \mathrm{CP}$. En otras palabras, si lo hiciera un tercero con consentimiento del dueño, no se le castigaría; en cambio, si lo hiciera el propio dueño, sí se le sancionaría. Esto no es lógico.

En consecuencia, la expresión "dueño", contenida en el artículo 432 CP., debe ser entendida en forma amplia, comprensiva también del mero tenedor de la cosa que se sustrae.

Como resulta obvio, la ausencia de voluntad del dueño, entendido éste en sentido amplio, no debe estar referida al aspecto material de la salida de la cosa de la esfera de custodia de su titular, sino a su aspecto jurídico ${ }^{44}$. Si acepta sólo la entrega de la cosa, no está consintiendo realmente en su apropiación.

Para que el consentimiento del dueño de la cosa pueda convertir en atípica la apropiación de ésta por un tercero, es necesario que cumpla ciertos requisitos, tanto en lo que respecta a su temporalidad como a su validez.

Desde el punto de vista temporal, el consentimiento debe existir antes de la apropiación. Si es posterior, la exigencia legal estará satisfecha ${ }^{45}$.

\footnotetext{
${ }^{41}$ En este sentido, García Arán, Delitos contra el patrimonio, cit. (n. 36), pp. 619 s.

${ }^{42}$ Este es el planteamiento de SChepeler VÁs 14), p. 56.

${ }^{43}$ Implícitamente, Quintero Olivares, Delitos contra el patrimonio, cit. (n. 36), p. 594.

${ }^{44}$ Etcheberry, Derecho penal, cit. (n. 8), III, p. 304.

${ }^{45}$ Ibíd.
} 
Un sector de la doctrina sostiene que la voluntad del dueño no sólo puede existir antes del apoderamiento, sino también durante éste ${ }^{46}$. Según nuestra opinión, esta afirmación debe ser matizada. Si después de iniciada la ejecución del delito y antes de su consumación, el dueño consiente en la apropiación de la cosa, ciertamente no podrá apreciarse un hurto o robo consumado, pero al menos habrá alcanzado a realizarse el correspondiente tipo penal de tentativa ${ }^{47}$.

En relación con su validez, el consentimiento debe emanar de una persona con capacidad para ello y estar exento de vicios. En cuanto a la capacidad, un sector de la doctrina plantea que no es posible considerar capaces a los dementes y a los menores de edad ${ }^{48}$. A nuestro juicio, el examen de este requisito debe realizarse caso a caso, sin que sea imprescindible la aplicación de las normas civiles. Si bien es cierto que, en general, los menores de edad y los dementes no tienen capacidad para disponer de sus bienes, también lo es que, a veces, en la vida diaria se les reconoce dicha capacidad. Por ejemplo, no parece discutible que un niño pueda disponer de la suma de dinero que diariamente le dan sus padres para comprar golosinas en el colegio. Pero sí lo parece el hecho de que pueda disponer del computador personal portátil que sus padres le han regalado para su cumpleaños ${ }^{49}$. En suma, no pueden darse reglas absolutas en esta materia. De lo contrario, "aun la venta de un dulce a un menor sería un hurto, puesto que el menor no pagaría, sino que sufriría la sustracción, sin su consentimiento, del dinero que entrega, lo que resulta insostenible"s0.

Por otro lado, el consentimiento debe estar exento de vicios. Esto no quiere decir que si está viciado no hay delito alguno. Sólo significa que el hecho no será sancionado a título de hurto, pero podrá serlo a otro título. Por ejemplo, si el consentimiento se obtiene mediante intimidación, habrá un robo; si se lo consigue mediante engaño, habrá estafa ${ }^{51}$.

La ausencia de voluntad del dueño, como cualquier otro requisito típico, debe ser probada en juicio por la acusación, por lo que no cabe presumirla. En algunas sentencias del Tribunal Supremo español se ha sostenido, a partir de la constatación de que no es necesario que el consentimiento del dueño

${ }^{46}$ Así, Garrido Montt, Derecho penal, cit. (n. 5), IV, p. 168.

${ }^{47}$ En este sentido, SChepeler VÁsquez, El delito de hurto, cit. (n. 14), p. 58, quien denomina a esta hipótesis como "consentimiento concomitante".

${ }^{48}$ Cfr. Etcheberry, Derecho penal, cit. (n. 8), III, p. 304; Bullemore - MACKInnon, Curso, cit. (n. 8), IV: Parte especial, p. 20.

${ }^{49}$ Véase Garrido Montt, Derecho penal, cit. (n. 5), IV, p. 169, sosteniendo la misma idea a partir de ejemplos similares.

${ }^{50}$ Politoff - Matus - Ramírez, Lecciones, cit. (n. 7), pp. $420 \mathrm{~s}$.

${ }^{51}$ Etcheberry, Derecho penal, cit. (n. 8), III, p. 304. 
sea expreso para eliminar la tipicidad del comportamiento, que la falta de voluntad se presume ${ }^{52}$. A nuestro juicio, esto es inaceptable, por contradecir la garantía de presunción de inocencia, al producir una alteración en la carga de la prueba. En efecto, una manifestación de dicha garantía la constituye el hecho de que a la acusación corresponde la carga de acreditar todos los elementos que fundan la responsabilidad penal, de modo que si no consigue llevar al tribunal al grado de convicción exigido para condenar, éste debe absolver al acusado ${ }^{53}$. Uno de tales elementos es, para efectos del hurto y del robo, la ausencia de voluntad del dueño, por lo que debe ser probado, so pena de absolverse al imputado. Pero no es necesario que ello se realice mediante prueba directa. Esto sería algo excepcional. Lo frecuente será que se acredite a través de indicios a partir de la restante prueba rendida en el juicio ${ }^{54}$. Ello, especialmente en los casos de hurto, ya que cuando se trata de un robo, la superación de obstáculos interpuestos por el dueño de la cosa a través de la violencia o la intimidación en las personas o la fuerza en las cosas, permite demostrar más fácilmente su falta de consentimiento ${ }^{55}$.

Pero esto no significa que el hurto necesariamente sea clandestino, requisito que por lo demás la ley no exige. La apropiación en el hurto generalmente es efectuada en forma oculta ${ }^{56}$. pero es perfectamente posible que se realice en forma tal que el dueño de la cosa se dé cuenta de la sustracción. Imagínese, por ejemplo, el caso de una enfermera, que en presencia de un paciente hospitalizado que, a pesar de estar consciente, no puede moverse de su cama, porque se encuentra recién operado, se apropia de sus pertenencias.

b) Presencia de ánimo de lucro. El citado artículo 432 CP. exige que quien se apropie de la cosa objeto del delito lo haga con ánimo de lucro. Se trata de una especial motivación que es necesario que esté presente en el agente al momento de realizar la conducta, con independencia de que efectivamente llegue a conseguir su propósito de lucrar.

Son varias las legislaciones penales extranjeras en las que es posible encontrar una exigencia subjetiva de esta clase. Así sucede, por ejemplo, en los Códigos Penales hondureño (artículo 223), salvadoreño (artículo 207), colombiano (artículo 239), peruano (artículo 185), venezolano (artículo

${ }^{52}$ Véanse sus sentencias de fechas 11 de julio de 1984, 14 de julio de 1982 y 3 de febrero de 1971, citadas por García Arán, Mercedes, El delito de hurto (Valencia, Tirant lo Blanch, 1998), p. 120.

${ }^{53} \mathrm{Cfr}$. Binder, Alberto, Introducción al derecho procesal penal ( 2 a edición, Buenos Aires, Ad Hoc, 2004), pp. 126-129.

${ }^{54}$ Garrido Montt, Derecho penal, cit. (n. 5), IV, pp. 169 ss.

${ }^{55}$ García Arán, El delito de hurto, cit. (n. 52), p. 121.

${ }^{56}$ Garrido Montt, Derecho penal, cit. (n. 5), IV, p. 168: "El apoderamiento en el delito de hurto es clandestino normalmente". 
451), italiano (artículo 624) y español (artículo 234), en los que se contienen expresiones tales como "con ánimo de lucro", "para obtener un provecho", "para aprovecharse de los bienes", etcétera.

No existe total acuerdo acerca de lo que significa el ánimo de lucro. Algunos afirman que consiste en la intención de lograr una ventaja de índole exclusivamente patrimonial ${ }^{57}$. Otros sostienen que consiste en el propósito de obtener un provecho o utilidad cualquiera ${ }^{58}$. No puede dejar de reconocerse que la fórmula escogida por el legislador nacional se muestra más restringida que la que se observa en ciertas legislaciones extranjeras que sólo exigen la búsqueda de algún provecho. La voz "lucro" parece sugerir la idea de un beneficio económico, lo que podría dar pie para optar por la interpretación restrictiva. Sin embargo, no creemos que haya problema en interpretar la expresión "ánimo de lucro" como la búsqueda de cualquier ventaja. La literalidad del precepto no lo impide. En efecto, conforme al diccionario de la lengua de la Real Academia Española, la locución "lucro" significa "ganancia o provecho que se saca de algo", y la voz "provecho", en su primera acepción, "beneficio o utilidad que se consigue o se origina de algo o por algún medio". En consecuencia, el ánimo de lucro puede interpretarse como el propósito de obtener un provecho cualquiera.

La opción por la interpretación extensiva se ve reforzada si se toma en cuenta que la restrictiva conduciría a que sólo podrían cometer hurto o robo quienes sustrajeran la cosa para venderla, arrendarla o explotarla en forma semejante $^{59}$, lo que parece no corresponder a la voluntad de la ley, porque dejaría fuera del precepto muchos casos en que el sujeto simplemente se queda con la cosa sustraída para usarla. En todo caso, es exigible que el provecho buscado sea apreciable pecuniariamente ${ }^{60}$, ya que de lo contrario no sería posible distinguir esta figura del comportamiento consistente en sustraer la cosa para destruirla, hipótesis que configuraría un delito de daños.

Otro punto discutido en la doctrina es el relativo a si existe o no una relación lógica entre el ánimo de lucro y el ánimo de señor y dueño o ánimo de apropiación. Algunos autores señalan que entre ambos ánimos media una relación de género a especie, siendo el ánimo de lucro el género y el de apropiación la especie. Así las cosas, la exigencia legal de ánimo de lucro sería superflua, ya que el ánimo de apropiación estaría incluido en éste ${ }^{61}$. Otros

${ }^{57}$ Así, Politoff - Matus - Ramírez, Lecciones, cit. (n. 7), p. 306; Garrido Montt, Derecho penal, cit. (n. 5), IV, p. 170.

${ }^{58}$ En este sentido, ETCheberry, Derecho penal, cit. (n. 8), III, p. 306.

${ }^{59}$ Ibíd.

${ }^{60}$ Ibíd.

${ }^{61}$ Así, Politoff Lifschitz, Sergio, El delito de apropiación indebida (Santiago, Editorial Jurídica ConoSur, 1992), pp. 241-245; Politoff - Matus - RamíreZ, Lec- 
sostienen que no existe dicha relación y que puede haber ánimo de apropiación sin ánimo de lucro, como por ejemplo, cuando se realiza la acción para perjudicar a la víctima, destruyendo la cosa u ocultándola, y también ánimo de lucro sin ánimo de apropiación, como por ejemplo, cuando se sustrae la cosa para obtener un dinero dándola en arriendo y restituirla pocas horas después $^{62}$. Esta segunda opinión, cuyos mantenedores pueden remontar hasta Paulo $^{63}$, es de antigua raigambre en la tradición española y en la italiana ${ }^{64}$.

Como se advertirá, esta discusión pone de relieve la existencia de una nueva divergencia, no explicitada, acerca de lo que significa el lucro. Quienes afirman que entre el lucro y la apropiación existe una relación de género a especie, respectivamente, lo hacen concibiendo al lucro como el propio del hurto o robo que revela la intención de apropiarse de la cosa, de incorporarla al propio patrimonio. En cambio, quienes niegan la existencia de dicha relación, lo hacen a partir de una noción de lucro que pone énfasis en el simple aprovechamiento de la cosa derivado de su uso ${ }^{65}$.

Como lo dijimos más arriba, nos decantamos por una noción amplia de ánimo de lucro, que lo concibe como el propósito de obtener un provecho cualquiera de la cosa sustraída, apreciable pecuniariamente, razón por la cual nos parece que el ánimo de lucro y el ánimo de señor y dueño son elementos subjetivos diferentes; puede concurrir el primero sin el segundo y viceversa. En consecuencia, no se verifica el hurto si la cosa es apropiada para alcanzar

ciones, cit. (n. 7), pp. 306 s.; Labatut Glena, Derecho penal, cit. (n. 6), II, p. 196. En el mismo sentido, en la doctrina española, Queralt Jiménez, Derecho penal, cit. (n. 36), pp. 394 s.; Serrano Gómez - Serrano Maíllo, Derecho penal, cit. (n. 24), pp. 353 s.; Muñoz Conde, Derecho penal, cit. (n. 36), p. 375. En la jurisprudencia, puede verse la sentencia de la Corte de Apelaciones de Talca, de 14 de septiembre de 2007, dictada en causa rol No 438-2007.

${ }^{62}$ Etcheberry, Derecho penal, cit. (n. 8), III, p. 305; Garrido Montt, Derecho penal, cit. (n. 5), IV, pp. 170 s.; SANHueza Romero, Juana, Delito de hurto y robo con fuerza en las cosas, en Revista de Derecho de la Universidad de Concepción, año LXIX, 209 (enero-junio 2001), p. 51. En la doctrina española, Rodríguez Devesa, José María, Hurto, en Nueva Enciclopedia Jurídica (Barcelona, Seix, 1979), XI, p. 201; implícitamente, Quintero Olivares, Delitos contra el patrimonio, cit. (n. 36), p. 595.

${ }^{63}$ Blasco Fernández de Moreda, Hurto, cit. (n. 30), pp. 665 s. En el Digesto se lee lo siguiente: "Furtum est contrectatio rei fraudulosa, lucri faciendi gratia vel ipsius rei, vel etiam usus eius, possinisve" ("El hurto es la sustracción fraudulenta de una cosa, con intención de lucro, ya sea de la cosa misma, o de su uso o posesión, lo cual se considera prohibido por la ley natural"), citado por Robledo Villar, Antonio, Delitos contra el patrimonio y el orden socioeconómico. Comentarios a los artículos 234 a $289 \mathrm{del}$ nuevo Código Penal (Barcelona, Bosch, 1997), p. 20.

${ }^{64}$ Cfr. Carrara, Francesco, Programa de Derecho criminal. Parte especial (trad. Ortega Torres - Guerrero, Bogotá, Temis, 1959), IV, \$2035, pp. 38 s.

${ }^{65}$ Véase García Arán, El delito de hurto, cit. (n. 52), p. 125. 
un fin distinto de la obtención de una utilidad pecuniariamente apreciable que emane de ella, como por ejemplo, sólo para esconderla.

Es cierto que la doctrina actualmente mayoritaria en España, cuyo Código Penal contiene una exigencia subjetiva similar a la nuestra, sostiene que el ánimo de lucro debe ser interpretado como ánimo de apropiación ${ }^{66}$. Lo hace principalmente para evitar concluir que el llamado hurto de uso deba sancionarse, dado que en el tipo penal del hurto se emplea la voz "tomar" ${ }^{\text {" }}$. Esto podría hacer pensar que en el Código Penal chileno la expresión "ánimo de lucro" resulta inútil, porque la conducta se describe como apropiarse, lo que además del apoderamiento mediante sustracción supone ánimo de señor y dueño ${ }^{68}$. Sin embargo, de ello no necesariamente se colige que el ánimo de lucro deba ser entendido como animus rem sibi habendi, ya que también puede plantearse que, además del ánimo de lucro, debe concurrir el ánimo de apropiación, por tratarse de elementos diferentes ${ }^{69}$. Esta es, precisamente, nuestra opinión.

Otra cuestión debatida es la relativa a determinar si es posible la concurrencia conjunta del ánimo de lucro y del ánimo de hacerse pago con la cosa perteneciente al deudor. Por un lado, un sector aparentemente mayoritario de la doctrina plantea que cuando el acreedor se apropia de una cosa perteneciente a su deudor para satisfacer con ella su crédito, no existe en su actuar ánimo de lucro, porque por una parte su patrimonio no aumenta, al recuperar lo que le pertenece, y por la otra, el patrimonio del deudor no disminuye, al quedar pagada su deuda, por lo que no se comete hurto ni robo ${ }^{70}$. Otro sector

${ }^{66}$ Por todos, Muñoz Conde, Derecho penal, cit. (n. 36), p. 375.

${ }^{67}$ Artículo 234, inciso $1^{\circ}$ del Código Penal español: "El que, con ánimo de lucro, tomare las cosas muebles ajenas sin la voluntad de su dueño será castigado, como reo de hurto, con la pena de prisión de seis a dieciocho meses, si la cuantía de lo sustraido excede de 400 euros".

${ }^{68}$ Cfr. Politoff - Matus - Ramírez, Lecciones, cit. (n. 7), p. 307.

${ }^{69}$ Así, González Rus, Juan José, Delitos contra el patrimonio y contra el orden socioeconómico, en Coвo Del Rosal (coordinador), Derecho penal español. Parte especial ( $2^{\text {a }}$ edición, Madrid, Dykinson, 2005), p. 458: "Junto al ánimo de lucro ha de concurrir el ánimo de apropiación”. Mencionando ambas posibilidades interpretativas, puede verse Robles Planas, Ricardo, Delitos contra el patrimonio, en Silva SánCHEZ (director), RAgués I VALLÈs (coordinador), Lecciones de Derecho penal. Parte especial ( $2^{a}$ edición, Barcelona, Atelier, 2009), p. 189, quien para evitar confundir el hurto típico con el llamado hurto de uso, generalmente impune, plantea la necesidad de exigir, "ya sea junto al ánimo de lucro, ya sea como precisión del mismo, el ánimo de apropiación”.

${ }^{70}$ En este sentido, Garrido Montt, Derecho penal, cit. (n. 5), IV, p. 171. Véase también la sentencia (de reemplazo) de la Corte Suprema de fecha 31 de julio de 2001, dictada en causa rol $\mathrm{N}^{\circ} 1790-01$ (considerando $3^{\circ}$ ). En la doctrina española, por todos: GonZÁlez Rus, Delitos contra el patrimonio, cit. (n. 69), p. 459. 
de la doctrina sostiene que la presencia del ánimo de lucro es compatible con la del ánimo de hacerse pago ${ }^{71}$.

A nuestro juicio, en esta materia deben efectuarse ciertas precisiones. Si el ánimo de lucro consiste en el propósito de obtener un provecho cualquiera de la cosa sustraída, apreciable pecuniariamente, es evidente que esta motivación puede estar presente cuando el sujeto activo busca hacerse pago con ella. El ánimo de hacerse pago no es incompatible con el ánimo de lucro ${ }^{72}$. Por ejemplo, un acreedor podría apropiarse de una cosa perteneciente a su deudor para satisfacer así su crédito, y además para darla en arriendo a un tercero. Por otro lado, no es efectivo que no haya ánimo de lucro cuando el patrimonio del sujeto activo no se vea aumentado y el del sujeto pasivo no se vea disminuido, ya que ello conduciría a negar la existencia del delito de hurto o robo cuando el agente, al apropiarse de la cosa ajena, dejara en su lugar una suma de dinero superior al valor de ésta ${ }^{73}$, algo que, en general, la doctrina no acepta.

Sin embargo, esta compatibilidad entre ambos ánimos no es suficiente argumento para defender el castigo a título de hurto o robo de tales comportamientos. Una interpretación sistemática, que tome en cuenta lo que prevé el artículo $494 \mathrm{~N}^{\circ} 20 \mathrm{CP}$., permite concluir que no resulta procedente la sanción a dicho título. Esta última disposición tipifica una forma de realización arbitraria del propio derecho y sanciona con pena de falta (multa de una a cuatro unidades tributarias mensuales) al que con violencia se apoderare de una cosa perteneciente a su deudor para hacerse pago con ella. Esto demuestra que no es voluntad de la ley castigar como hurto o robo la conducta señalada. Como el legislador considera este comportamiento una falta y sólo si media violencia, es absurdo imponer una pena más grave y

${ }^{71}$ Así, Schepeler VÁsquez, El delito de hurto, cit. (n. 14), p. 51; Mera FigueROA, Jorge, Ánimo de lucro en el hurto. Comentario a sentencia de la Corte de Apelaciones

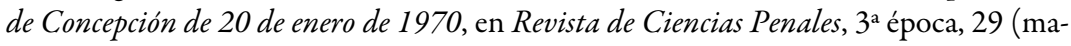
yo-agosto 1970) 2, , p. 160; BAscuñán RodrígueZ, Antonio, El robo como coacción, en Revista de Estudios de la Justicia, 1 ()Centro de Estudios de la Justicia, Facultad de Derecho, Universidad de Chile, 2002), p. 95; Sото Piñeiro, Miguel, Comentario a sentencia, en Revista de Ciencias Penales, 4a época, 39 (1987-1989) 2, p. 111; implícitamente, El Mismo, El hurto del acreedor: ¿una conducta atipica? en Revista de Ciencias Sociales. Derecho y Sociedad, 3-4 (1989), p. 33.

${ }^{72}$ Considerando que el ánimo de hacerse pago es una modalidad del ánimo de lucro: Bajo Fernández, Miguel, Ánimo de lucro y ánimo de hacerse pago, en Revista de Derecho Público, 2a época, año 11, 1 (Madrid, 1976), pp. 45-63; Mañalich Raffo, Juan Pablo, Autotutela del acreedor y protección penal del deudor. La realización arbitraria del propio derecho frente a los delitos contra la libertad, la propiedad y el patrimonio (Santiago, Ediciones Jurídicas de Santiago, 2009), pp. 91-94.

${ }^{73}$ Bajo Fernández, Ánimo de lucro, cit. (n. 72), p. 61. 
calificar el hecho como hurto cuando no existe tal violencia (la ausencia de ésta es uno de los requisitos negativos que, para el delito de hurto, exige el artículo 432 del mencionado Código ${ }^{74}$. Por lo tanto, si existe violencia, se configura la mencionada falta; si no, la conducta es impune.

En todo caso, esta afirmación también debe ser matizada. Cuando el acreedor se apropia de una cosa que pertenece al deudor, siendo la deuda exigible y el objeto material de la acción es la cosa debida (el cuerpo cierto en una obligación específica de entregar una cosa determinada o la cantidad de dinero correspondiente al monto de una obligación pecuniaria), la conducta configura el mencionado delito de realización arbitraria del propio derecho si media violencia, y es impune en caso contrario. Pero si la deuda aún no es exigible, o si siéndolo, el acreedor se apropia de cosa distinta de la que es debida o incluso toma el equivalente de lo debido en una obligación de género (un bien mueble de valor similar al del monto de la obligación dineraria o una especie cualquiera del género correspondiente a la obligación no monetaria), el comportamiento da lugar al delito de hurto o robo. Esto es así, porque a diferencia de lo que sucede en la primera hipótesis, en la que no disminuyen las posibilidades del propietario como tal, porque éste no puede dar a la cosa otro destino que el de entregarla al acreedor, en los últimos casos tales posibilidades sí se ven menguadas ${ }^{75}$. Verbigracia, antes de que una obligación de especie o cuerpo cierto sea exigible, el deudor podría obtener algún provecho económico de la cosa debida; después de que una obligación pecuniaria sea exigible, podría pedir dinero prestado para pagar la deuda; después de que una obligación de género no monetaria sea exigible, podría escoger cualquier individuo del género de calidad mediana para pagar la deuda (artículo 1509 CC.), etc. En consecuencia y por mencionar sólo algunos ejemplos de lo que se acaba de explicar, si antes de que la deuda sea exigible el acreedor se apropia del computador de determinada marca y serie perteneciente al deudor, que éste se ha comprometido a entregarle, comete delito de hurto o robo, según corresponda. Si el comportamiento tiene lugar después de que la deuda se haga exigible, se configura el delito de realización arbitraria del propio derecho si media violencia, y es impune en caso contrario. Y si después de alcanzada dicha exigibilidad, para hacerse

${ }^{74}$ Cfr. Politoff - Matus - Ramírez, Lecciones, cit. (n. 7), p. 300; Garrido Montt, Derecho penal, cit. (n. 5), IV, pp. 171 s.; Schepeler VásQuez, El delito de burto, cit. (n. 14), p. 51; Aguilar Aranela, Delitos patrimoniales, cit. (n. 25), p. 34.

${ }^{75}$ Así, Bajo Fernández, "Ánimo de lucro y ánimo de hacerse pago”, pp. 68 s.; en el mismo sentido, pero aludiendo sólo a los casos de deuda no exigible, García Arán, El delito de hurto, cit. (n. 52), pp. 136 s. Similar, BAscuñán Rodríguez, "El robo como coacción”, p. 96; MaÑalich RafFo, Autotutela del acreedor y protección penal del deudor..., pp. 60-64. 
pago, el acreedor se apropia de un televisor del deudor, aunque su valor sea equivalente al del computador, comete hurto o robo, según corresponda.

Otro punto que merece la pena destacar en relación con la exigencia subjetiva del ánimo de lucro es la relativa a la determinación de la persona que se espera que se vea beneficiada con la acción que se realiza. La doctrina suele afirmar que es indiferente la determinación de la persona a quien se pretende beneficiar y que el lucro o provecho buscado puede ser tanto propio como ajeno $^{76}$. Lo mismo acostumbra sostener la jurisprudencia ${ }^{77}$.

Según nuestra opinión, esta afirmación puede aceptarse en legislaciones en las que al aludir a esta exigencia subjetiva, se hace referencia expresa tanto al provecho que el sujeto activo busca para sí como al que busca para terceros. Es esto lo que sucede, por ejemplo, en los Códigos Penales brasileño (artículo 155), salvadoreño (artículo 207), colombiano (artículo 239) e italiano (artículo 624). Incluso, podría sostenerse en legislaciones en las que dicha exigencia se encuentra establecida en términos genéricos, sin precisar si se busca un lucro o provecho propio o ajeno, argumentando que no distinguiendo la ley, se comprenden ambas posibilidades. Así ocurre, verbigracia, en los Códigos Penales peruano, cuyo artículo 185 exige que se obre "para obtener provecho", y español, cuyo artículo 234 exige que se actúe "con ánimo de lucro"78. Pero no puede ser aceptada en Chile, ya que el artículo 432 de nuestro Código Penal no exige que se obre, simplemente, con ánimo de lucro, sino "con ánimo de lucrarse". Como puede advertirse, el legislador ha empleado una especie de verbo pronominal, concretamente uno cuasirreflejo, al construirlo con un pronombre reflexivo, ya que el sujeto del verbo y el término del complemento son una misma persona ${ }^{79}$. Esto implica que la exigencia subjetiva sólo puede entenderse cumplida cuando el agente se apropia de la cosa ajena con el propósito de obtener él mismo y no otra persona, un lucro. Y como hemos afirmado que el lucro es cualquier provecho

${ }^{76}$ Véase Politoff - Matus - Ramírez, Lecciones, cit. (n. 7), p. 306; Garrido Montt, Derecho penal, cit. (n. 5), IV, p. 170; Eтcheberry, Derecho penal, cit. (n. 8), III, p. 306; Bullemore - Mackinnon, Curso, cit. (n. 8), IV: Parte especial, p. 21.

${ }^{77}$ Entre otras, véase la sentencia de la Corte de Apelaciones de Antofagasta, de 11 de julio de 2008, dictada en causa rol No 137-2008.

${ }^{78}$ En la doctrina española, aceptan que el lucro buscado puede ser tanto propio como ajeno, entre otros: González Rus, Delitos contra el patrimonio „ cit. (n. 69), p. 458; Muñoz Conde, Derecho penal, cit. (n. 36), p. 375; Rodríguez Devesa, José María - Serrano Gómez, Alfonso, Derecho penal español. Parte especial (18 a edición, Madrid, Dykinson, 1995), pp. 419 s.; Serrano Gómez - Serrano Maíllo, Derecho penal, cit. (n. 24), p. 353.

${ }^{79}$ Bello, Andrés - Cuervo, Rufino, Gramática de la lengua castellana (Buenos Aires, Spena Argentina, 1945), p. 246; Revilla de Cos, Santiago, Gramática española moderna (2a edición, México, McGraw-Hill, 1986), p. 118. 
que se obtenga de la cosa, pecuniariamente apreciable, entonces sólo obra con ánimo de lucrarse quien ejecuta la acción con el propósito de obtener para sí y no para otra persona, un provecho que emane de la cosa, estimable pecuniariamente. En consecuencia, dados los términos empleados por el legislador en la redacción del citado artículo 432, si en un caso concreto se llegase a demostrar que la apropiación fue realizada para entregar inmediatamente la cosa a un tercero, a quien se pretendía beneficiar, la conducta no podría ser considerada típica ${ }^{80}$. Desde luego, estamos conscientes de las indeseables consecuencias político-criminales que nuestra opinión trae aparejadas, pero un estricto respeto del principio de legalidad nos obliga a mantenerla. No pueden estimarse incluidas las apropiaciones de cosas ajenas para beneficiar a terceros sin forzar el tenor literal de la mencionada disposición. Urge entonces una modificación legal en esta materia.

\section{OBJETO MATERIAL}

Tradicionalmente se ha entendido, al estudiar la teoría del delito, que el objeto material constituye la persona o cosa sobre la que recae físicamente la acción ${ }^{81}$. Pues bien, de la lectura del artículo 432 CP. se desprende que tanto el hurto como el robo poseen características comunes en lo que dice relación con el objeto material del delito, algunas de las cuales se encuentran explícitamente señaladas y otras sólo en forma implícita. Nos referimos a las calidades de corporal, mueble, ajena y susceptible de apropiación y apreciación pecuniaria, que la cosa debe tener. A continuación examinaremos cada una de dichas características.

\section{Cosa corporal.}

Conforme al citado artículo 432, el objeto material del hurto y del robo es una cosa mueble. A su turno, de acuerdo con disposiciones del Código Civil, no sólo pueden ser muebles las cosas corporales, esto es, aquellas que tienen un ser real y pueden ser percibidas por los sentidos, sino también las incorporales, es decir, las que consisten en meros derechos (artículos 565, 566 y 580). Esto

${ }^{80}$ Resulta sorprendente el hecho de que quienes en la doctrina nacional sostienen, al igual que nosotros, que no existe relación de género a especie entre el ánimo de lucro y el ánimo de apropiación, afirmen que el hurto es típico, tanto cuando el beneficio se pretende obtener para el propio sujeto activo, como cuando se lo quiere conseguir para un tercero. Es el caso, por ejemplo, de ETcheberRy, Derecho penal, cit. (n. 8), III, p. 306; Garrido Montt, Derecho penal, cit. (n. 5), IV, p. 170.

${ }^{81}$ Por todos: Mir Puig, Santiago, Derecho penal. Parte general ( $7^{\text {a }}$ edición, B de F, Buenos Aires - Montevideo, 2004, p. 224. 
obliga, antes de examinar el significado de la voz "mueble", a analizar si el objeto material de estos delitos es una cosa corporal o incorporal.

Atendido el hecho de que la conducta típica consiste en apoderarse de una cosa mediante su sustracción, con ánimo de señor y dueño, es evidente que dicha cosa no puede ser incorporal. Por su propia naturaleza, los derechos reales o personales no pueden ser sustraídos de una esfera de custodia o resguardo. El objeto material del delito es, pues, una cosa corporal.

Sin embargo, la doctrina nacional suele señalar que el concepto civil de cosa corporal no resulta aplicable en esta materia, porque existen ciertas cosas que a pesar de que tienen un ser real y pueden ser percibidas por los sentidos, no se las considera un posible objeto material de estos delitos, ya que no pueden ser aprehendidas y desplazadas de un lugar a otro, como por ejemplo, el sonido, la luz, el calor, el frío, las energías ${ }^{82}$. Con mayor precisión, entonces, la doctrina plantea que además de que sean reales y puedan ser percibidas por los sentidos, deben tener cierta extensión, ocupar un lugar en el espacio ${ }^{83}$.

El punto ha cobrado especial relevancia en lo que dice relación con la energía eléctrica. Por la falta de corporeidad que se le ha atribuido, algunos autores afirman que no resulta posible un hurto o un robo de electricidad y que tal es la razón por la que fue necesario crear una figura especial, contenida en el Decreto con fuerza de ley $N^{\circ} 1$, de 1982, del Ministerio de Minería, cuyo actual texto refundido, coordinado y sistematizado fue fijado por el Decreto con fuerza de ley No 4, de 2007, del Ministerio de Economía, Fomento y Reconstrucción, figura a la que, paradójicamente, se conoce con el nombre de hurto de energía eléctrica, aplicable, en términos generales, en los casos de consumo clandestino o fraudulento de dicha energía ${ }^{84}$.

Según nuestra opinión, es perfectamente posible considerar como cosa corporal la energía eléctrica, y como hurto o robo, una sustracción de electricidad. Es claro que dicha energía forma parte de la realidad natural y puede ser percibida por los sentidos. Basta con introducir los dedos en una toma de corriente para comprobarlo ${ }^{85}$. Además, no es cierto que no tenga corporei-

\footnotetext{
${ }^{82}$ Así, Etcheberry, Derecho penal, cit. (n. 8), III, p. 299; Garrido Montt, Derecho penal, cit. (n. 5), IV, p. 162.

${ }^{83}$ Por todos: Labatut Glena, Derecho penal, cit. (n. 6), II, p. 199.

${ }^{84}$ Así, Politoff - Matus - Ramírez, Lecciones, cit. (n. 7), pp. 303 y 322; ETCheberry, Derecho penal, cit. (n. 8), III, p. 299; Garrido Montt, Derecho penal, cit. (n. 5), IV, p. 162. En contra, aceptan la posibilidad de un hurto de electricidad: Guzmán Dálbora, José Luis, El hurto de energía eléctrica, en El mismo, Estudios y defensas penales (3a edición, Santiago, Legal Publishing, 2009), pp. 57-63; SCHEPELER VÁsQuez, El delito de hurto, cit. (n. 14), pp. 21-24; Del Río, Derecho penal, cit. (n. 13), III, p. 428.

${ }^{85}$ Cfr. Guzmán Dálbora, El hurto de energía eléctrica, cit. (n. 84), p. 59: "La
} 
dad. Como bien se encarga el profesor Guzmán Dálbora de recordárnoslo, la Física moderna ha superado la antigua separación entre materia y energía. Actualmente se sostiene que toda materia está compuesta de electricidad y que los iones (elementos básicos de la energía eléctrica) tienen un soporte material. Por lo tanto, si materia y energía son sólo dos formas de aparición de un mismo sustrato, no tiene sentido negar a la segunda su existencia individual por una supuesta falta de delimitación. La energía eléctrica es materia e incluso puede ser separada del aparato que la genera ${ }^{86}$.

Por otra parte, la forma en que está descrita la conducta punible en el tipo de hurto de electricidad aporta otro argumento a favor de nuestra opinión. El artículo 215 del citado Decreto con fuerza de ley No 4, de 2007, sanciona el comportamiento de sustraer energía eléctrica. No resultaría posible realizar esta acción si tal energía no tuviera materialidad ni ocupara un lugar en el espacio.

Por lo demás, una interpretación progresiva o evolutiva de la expresión "cosa" contenida en el artículo $432 \mathrm{CP}$. no puede quedar congelada en su sentido originario, sino que debe tomar en cuenta las modificaciones que se producen en la sociedad para adaptarse a las necesidades actuales ${ }^{87}$. Una de tales modificaciones -a estas alturas, ya no tan reciente- ha sido precisamente el surgimiento de la electricidad.

En consecuencia, con independencia del hecho de que existe una ley especial que sanciona la conducta -lo que plantea un problema, porque daría pie para sostener que la sustracción no autorizada de otras energías no estaría sancionada $-{ }^{88}$, la energía eléctrica reúne las condiciones necesarias para ser objeto material de un hurto o un robo. La definición civil de cosa corporal puede ser aplicada sin problemas en esta materia.

Lo dicho permite considerar también como objeto material de tales deli-

energía eléctrica [...] calza a pedir de boca en la definición del artículo 565, párrafo segundo, del Código del ramo" (civil) (p. 60). En el mismo sentido, Claro Solar, Luis, Las sustracciones de electricidad ante la ley penal, en Revista de Derecho y Jurisprudencia, 25 (julio-agosto 1928) 5-6, p. 66.

${ }^{86}$ Guzmán DÁlbora, El hurto de energía eléctrica, cit. (n. 84), pp. 57 s. Similar: Ugarte, José Manuel - Von Lapcevic, Sascha, Hurto de energía eléctrica. Sustracción, apoderamiento ilícito y fraude (Buenos Aires, Ediciones Depalma, 1975), p. 27.

${ }^{87}$ Cobo del Rosal, Manuel - Vives Antón, Tomás, Derecho penal. Parte general (5ª edición, Tirant lo Blanch, Valencia, 1999), p. 121.

${ }^{88}$ Guzmán Dálbora, El hurto de energía eléctrica, cit. (n. 84), p. 52. 
tos otras cosas, tales como los gases ${ }^{89}$, los $\operatorname{líquidos}^{90}, \operatorname{los}_{\text {fluidos }}{ }^{91}$, etcétera.

\section{Cosa mueble.}

El citado artículo 432 exige que la cosa apropiada sea mueble. Esta exigencia se encuentra en numerosas legislaciones extranjeras. Así ocurre, por ejemplo, en los Códigos Penales argentino (artículo 162), boliviano (artículo 326), brasileño (artículo 155), colombiano (artículo 239), costarricense (artículo 208), salvadoreño (artículo 207), guatemalteco (artículo 246), hondureño (artículo 217), mexicano (artículo 367), nicaragüense (artículo 263), panameño (artículo 181), paraguayo (artículo 161), peruano (artículo 185), uruguayo (artículo 340), venezolano (artículo 451), italiano (artículo 624), alemán (parágrafo 242) y español (artículo 234). Excepcionalmente, hay algunas legislaciones en las que no se exige de modo expreso que el objeto material del delito sea una cosa mueble, sino que se alude genéricamente a cosas o bienes, como sucede, verbigracia, en los Códigos Penales ecuatoriano (artículo 547) y francés (artículo 311-1), pero es evidente que de todas formas debe tratarse de una cosa mueble, ya que la conducta que en ellos se reprime es la de sustraer, lo que implica la posibilidad de aprehensión y desplazamiento.

Conforme al Código Civil, son muebles las cosas que pueden transportarse de un lugar a otro, sea moviéndose ellas a sí mismas, sea que sólo se muevan por una fuerza externa (artículo 567). El mismo Código distingue tres clases de cosas inmuebles: las que no pueden transportarse de un lugar a otro, como las tierras (inmuebles por naturaleza); las que adhieren permanentemente a ellas, como los árboles (inmuebles por adherencia) y las que están permanentemente destinadas al uso, cultivo y beneficio de ellas, como los animales destinados al cultivo de una finca, puestos en ella por el dueño de la misma (inmuebles por destinación) (artículos 568, 569 y 570 CC.).

El punto que debe captar nuestra atención en este momento es el relativo a si puede utilizarse en esta materia el concepto civil de cosa mueble. En este tema, una antigua opinión doctrinal postulaba que dicho concepto era aplicable ${ }^{92}$. La apropiación de una cosa adherida o permanentemente desti-

${ }^{89}$ Así, Schepeler Vásquez, El delito de hurto, cit. (n. 14), p. 21; Etcheberry, Derecho penal, cit. (n. 8), III, p. 299. En contra: GARRIDo MonTt, Derecho penal, cit. (n. 5), IV, p. 162.

${ }^{90}$ Cfr. Blasco Fernández de Moreda, Hurto, cit. (n. 30), p. 655.

${ }^{91}$ En contra: Politoff - Matus - Ramírez, Lecciones, cit. (n. 7), p. 303.

${ }^{92} \mathrm{Cfr}$. Alessandri Rodríguez, Arturo, Similitud del concepto de cosa mueble en el derecho civil y en el derecho penal, en Revista de Ciencias Penales, 2a época, 8 (1945), pp. 175-182. En el mismo sentido: Labatut Glena, Derecho penal, cit. (n. 6), II, pp. $198 \mathrm{~s}$. 
nada a un inmueble por naturaleza puede constituir un hurto o un robo, a pesar de que la ley civil la considera inmueble. Pero dicha opinión doctrinal planteaba que no por eso debía sostenerse que el concepto penal de cosa mueble era distinto del civil, porque conforme a la ley civil los inmuebles por adherencia o destinación pasan a ser muebles desde el instante mismo en que el ladrón realiza la apropiación. En efecto, por lo que respecta a los inmuebles por adherencia, conforme al artículo 573 CC., éstos no dejan de serlo por su separación momentánea, pero desde que se separan para darles un destino diferente, recuperan su calidad de muebles. Y en cuanto a los inmuebles por destinación, del artículo 570 del mismo Código se desprende que si desaparece su destino permanente, también vuelven a ser muebles. Como el ladrón sustrae la cosa inmueble por adherencia o destinación para darle un destino diferente, se trataría de una cosa mueble ${ }^{93}$.

Reconociendo la lucidez de dicha opinión, no resulta aceptable. Efectivamente, el citado artículo 573 señala que las cosas accesorias a bienes raíces no dejan de considerarse inmuebles por su momentánea separación, y lo que pretende el ladrón no es su separación momentánea, sino definitiva. Pero podría ocurrir que la cosa sea momentáneamente separada por su dueño, manteniendo por tanto su calidad de inmueble, y apropiada por un tercero durante dicha separación. Para el derecho penal podría haber un hurto o un robo, a pesar de que para la ley civil se trataría de una cosa inmueble ${ }^{94}$.

Además, dicha opinión no soluciona satisfactoriamente las hipótesis de tentativa, ya que mientras no tenga lugar la separación de la cosa del inmueble al que está adherida o destinada, no se trataría aún de cosa mueble para la ley civil. Haciéndose cargo de este punto, la opinión que criticamos sostenía que lo que devuelve al inmueble por adherencia o destinación su carácter de mueble no es tanto su efectiva separación, sino la voluntad de separarla definitivamente, creyendo ver en el artículo 571 CC. un argumento a favor de esta idea (el tenor de esta disposición es el siguiente: "Los productos de los inmuebles, y las cosas accesorias a ellos [...], se reputan muebles, aun antes de su separación, para el efecto de constituir un derecho sobre dichos productos o cosas a otra persona que el dueño") ${ }^{95}$. Pero es obvio que al apropiarse de la cosa, el ladrón no constituye ningún derecho sobre ella. Además, del artículo 573 del mismo Código no se desprende que las cosas accesorias a bienes raíces dejen

${ }^{93}$ Alessandri Rodríguez, Similitud del concepto de cosa mueble, cit. (n. 92), pp. 177-179.

${ }^{94}$ En este sentido, véase la crítica de Politoff Lifschitz, El delito de apropiación indebida, cit. (n. 61), p. 80.

${ }^{95}$ Alessandri Rodríguez, Similitud del concepto de cosa mueble, cit. (n. 92), p. 180. 
de ser inmuebles desde que se pretende separarlas con el objeto de darles un destino diferente, sino desde que efectivamente se separan con dicho fin ${ }^{96}$.

En consecuencia, el concepto civil de cosa mueble no es aplicable en esta materia. Para efectos del hurto y del robo, debe entenderse por cosa mueble cualquier objeto corporal que pueda moverse de un lugar a otro. Se trata, por ende, de un concepto más amplio que el civil. Así lo sostiene la mayoría de la doctrina nacional ${ }^{97}$.

En la doctrina extranjera también se propone un concepto de cosa mueble más amplio que el que proviene del derecho civil, y que en general sólo exige que se trate de un objeto del mundo exterior susceptible de apoderamiento material y de desplazamiento ${ }^{98}$.

En todo caso, debe tenerse presente que existen cosas que a pesar de ser muebles conforme al concepto señalado, no pueden ser objeto material del hurto ni del robo. Se trata de las aguas que se encuentran en cauces o depósitos naturales o artificiales, ya que ellas pueden ser objeto material de otro delito: el de usurpación (artículos 459 a 461 CP.). Pero si se encuentran envasadas, sí pueden ser objeto de hurto o robo ${ }^{99}$.

\section{Cosa ajena.}

Además de que la cosa apropiada sea mueble, el artículo $432 \mathrm{CP}$. requiere que sea ajena. Se trata de una exigencia que se encuentra en la mayoría de las legislaciones extranjeras. Así ocurre, por ejemplo, en los Códigos Penales argentino (artículo 162), boliviano (artículo 326), brasileño (artículo 155), colombiano (artículo 239), costarricense (artículo 208), ecuatoriano (artículo 547), salvadoreño (207), guatemalteco (artículo 246), hondureño (artículo 217), mexicano (artículo 367), nicaragüense (artículo 263), panameño (artículo 181), paraguayo (artículo 161), peruano (artículo 185), uruguayo (artículo 340), venezolano (artículo 451), francés (artículo 311-1), italiano (artículo 624), alemán (parágrafo 242) y español (artículo 234), textos normativos en los que se emplean expresiones tales como "ajena" "de otro", "perteneciente a otro", etcétera.

Que la cosa objeto del hurto o del robo sea ajena significa que no debe pertenecer al sujeto activo ${ }^{100}$.Esto no sólo puede deducirse del sentido natural

${ }^{96}$ Así, Vodanovic Hernán, en Alessandri Rodríguez - Somarriva Undurraga, Curso de Derecho Civil, redactado, ampliado y puesto al día por Vodanovic H. (3 a edición, Editorial Nascimento, Santiago, 1974), II: Los bienes y los derechos reales, pp. 39-41.

${ }^{97}$ Por todos, Garrido Montt, Derecho penal, cit. (n. 5), IV, p. 164.

${ }^{98}$ En la doctrina española, por todos: MuÑoz Conde, Derecho penal, cit. (n. 36), pp. 373 s.; SÁnChez Moreno, El hurto, cit. (n. 36), p. 10.

${ }^{99}$ Así, Etcheberry, Derecho penal, cit. (n. 8), III, p. 300.

${ }^{100}$ Una interesante sentencia de la Corte de Apelaciones de Concepción, de 25 
y obvio de la voz "ajena", sino del mismo texto del artículo 432. En efecto, éste exige que el agente se apropie de la cosa mueble, lo que sería imposible si quien realizara la acción fuese su propietario. Además, si fuera el dueño de la cosa quien la arrebatase de manos de su legítimo tenedor, se configuraría un delito distinto, tipificado en el artículo $471 \mathrm{~N}^{\circ} 1$, al que se conoce con el nombre de hurto de posesión.

Sin embargo, para que la cosa sea ajena no es suficiente que no pertenezca al sujeto activo. Además de ello, se requiere que pertenezca a otra persona ${ }^{101}$. El propio artículo 432 así lo siguiere, al exigir que se obre "sin la voluntad de su dueño".

Como se comprenderá, no es necesario que el sujeto activo conozca la identidad del dueño de la cosa de la que se apropia. Además, es indiferente que la única cosa apropiada pertenezca a una sola persona o a varias; en uno y otro caso, no habrá un concurso de delitos, sino sólo un delito de hurto o robo $^{102}$.

Como consecuencia de lo dicho acerca del significado de la ajenidad, existe consenso en que ciertas cosas no pueden ser objeto material de un hurto o un robo. Tal es el caso de las cosas que la naturaleza ha hecho comunes a todos los hombres, las cuales no son susceptibles de dominio y nadie puede apropiárselas (artículo 585 CC.). Otro tanto ocurre con las llamadas res nullius, que son las cosas que no pertenecen a nadie y que pueden ser adquiridas por ocupación (artículo 606 CC.). Lo mismo sucede con las denominadas res derelictae, es decir, las cosas que han sido abandonadas por su dueño para que cualquier persona se las pueda apropiar.

En todo caso, las cosas abandonadas no deben ser confundidas con las cosas extraviadas o perdidas, que sí son ajenas y cuya apropiación puede dar lugar al delito de hurto de hallazgo (artículo 448 CP.). También son ajenos los bienes nacionales de uso público, ya que si bien su uso corresponde a todos los habitantes de la nación, su dominio pertenece a la nación misma (artículo 589 CC. $)^{103}$.

Un punto especialmente discutido en la doctrina nacional, a propósito

de septiembre de 2009, dictada en causa rol № 444-2009, absolvió al imputado de la acusación de hurto que pesaba en su contra por haber entrado a un inmueble a sustraer madera, porque el bien raíz se encontraba inscrito a su nombre, por lo que si tenía la posesión inscrita de éste, la madera no podía ser considerada ajena.

${ }^{101}$ En contra, mencionando sólo la no pertenencia de la cosa al sujeto activo: $\mathrm{MU}$ Ñoz CONDE, Derecho penal, cit. (n. 36), p. 374.

${ }^{102}$ Politoff - Matus - Ramírez, Lecciones, cit. (n. 7), p. 304; Labatut Glena, Derecho penal, cit. (n. 6), II, p. 198.

${ }^{103}$ Así, en relación con los bienes nacionales de uso público: Etcheberry, Derecho penal, cit. (n. 8), III, p. 301. En contra: Garrido Montt, Derecho penal, cit. (n. 5), IV, p. 165; Politoff - Matus - Ramírez, Lecciones, cit. (n. 7), p. 303. 
de la ajenidad de la cosa objeto del delito de hurto o robo, es el relativo a la posibilidad de apreciar este delito cuando quien realiza la acción es un copropietario. La hipótesis que se tiene en mente es la del comunero que se apodera de la cosa común que está en manos de otro comunero. Algunos autores sostienen que en tal caso no puede apreciarse un hurto o un robo, porque mientras se tiene una cosa proindiviso no se puede hablar de cosa ajena en sentido estricto ${ }^{104}$. Otros afirman que puede configurarse el delito, porque se trataría de una cosa parcialmente ajena ${ }^{105}$. En la doctrina extranjera el tema también ha sido objeto de discusión ${ }^{106}$.

No existe en el Código Penal una figura destinada a sancionar específicamente estas conductas. En legislaciones extranjeras, en cambio, es frecuente encontrar disposiciones que sí lo hagan, apreciándose dos variantes. En algunas, se ha optado por incluir tales comportamientos mediante la introducción de una frase en el correspondiente tipo penal de hurto, que declara que la cosa objeto material del delito debe ser total o parcialmente ajena. Esto se observa, entre otros, en los Códigos Penales argentino (artículo 162), costarricense (artículo 208), salvadoreño (artículo 207), guatemalteco (artículo 246), nicaragüense (artículo 263) y peruano (artículo 185). En otras, se ha preferido incorporar una figura especial que cubra estas hipótesis. Así ocurre, entre otros, en los Códigos Penales boliviano (artículo 327), brasileño (artículo 156), colombiano (artículo 242), panameño (artículo 182), uruguayo (artículo 342), venezolano (artículo 451) e italiano (artículo 627).

A nuestro juicio y a pesar del silencio de nuestro Código sobre este punto, el hurto entre comuneros es admisible y puede ser sancionado. El hecho de que cuando la acción tiene lugar la cosa permanece indivisa y el sujeto activo tiene un derecho sobre ella, no impide afirmar que se está apropiando de algo ajeno: aquella parte del bien común a que no tiene derecho y que es extraña a su patrimonio. Esta parte es tan ajena como cualquier otra cosa de la que no sea comunero ${ }^{107}$.

Además, a la idea proveniente del derecho civil, de que el comunero se

${ }^{104}$ En este sentido: Politoff - Matus - Ramírez, Lecciones, cit. (n. 7), pp. 303 s.

${ }^{105}$ Así, Etcheberry, Derecho penal, cit. (n. 8), III, p. 303; Bullemore - MACKInnon, Curso, cit. (n. 8), IV: Parte especial, p. 18; SChepeler VÁsQuez, El delito de hurto, cit. (n. 14), pp. 45-48.

${ }^{106}$ En la doctrina española la opinión mayoritaria plantea que no puede apreciarse un delito de hurto (o robo) si la cosa sustraída está sometida a un régimen de copropiedad indivisible, pero sí si hay una división en cuotas proporcionales. Cfr. Robles PlaNAS, Delitos contra el patrimonio, cit. (n. 69), p. 188; GonZÁlez Rus, Delitos contra el patrimonio, cit. (n. 69), 458.

${ }^{107}$ Schepeler Vásquez, El delito de hurto, cit. (n. 14), p. 48. En el mismo sentido: Cuello Calón, Eugenio, Derecho penal. Parte especial (9a edición, Barcelona, 1955), II, pp. 793 s. 
entiende poseer por todos los demás y que a todos ellos les está permitido el uso de la cosa común, puede replicarse que el propio legislador civil reconoce la posibilidad del hurto entre comuneros herederos. En efecto, conforme al artículo $1231 \mathrm{CC}$., el heredero que sustrae objetos pertenecientes a una sucesión, además de perder la facultad de repudiar la herencia y de no tener parte alguna en los efectos sustraídos, quedará sujeto "criminalmente a las penas que por el delito correspondan". Como es obvio, este delito del comunero no puede ser otro que el de hurto (o robo) de la parte que no sea suya ${ }^{108}$.

Por otro lado, debe tenerse presente que en el título $4^{a}$ de la Ley general de hurtosy robos, de 1849 , se contemplaba una eximente de responsabilidad penal que se aplicaba cuando la cosa objeto del delito era de propiedad común. Como es sabido, al redactarse el Código Penal no se previó ninguna disposición similar, por lo que es posible entender que es voluntad de la ley sancionar el llamado "hurto entre comuneros".

Finalmente y como último argumento, el tenor literal del artículo 432 $\mathrm{CP}$., que simplemente alude a una cosa ajena, no resta fuerza a nuestra opinión, ya que nada impide entender incluidas, además de las cosas totalmente ajenas, las que lo son parcialmente.

\section{Cosa susceptible de apropiación.}

El citado artículo 432 no contempla una exigencia explícita de que el objeto material del delito de hurto o robo sea una cosa susceptible de apropiación. Pero es evidente que se trata de un requisito implícitamente exigido, ya que de lo contrario no podría realizarse la acción que se castiga (apropiarse).

En general, la doctrina suele señalar que sólo tienen el carácter de cosa susceptible de apropiación los objetos y los animales. No así las personas ${ }^{109}$. Los cadáveres tampoco pueden ser considerados cosas susceptibles de apropiación, sin perjuicio de la posible comisión de un delito de inhumación o exhumación ilegal (artículos 320 y 322 CP. . $^{110}$ o de violación de sepulcro o sepultura (artículo 321 CP.). Lo mismo sucede con las partes del cuerpo de una persona viva ${ }^{111}$.

Sin embargo, es necesario matizar estas afirmaciones. Si bien es cierto que los cadáveres no revisten el carácter de cosas susceptibles de apropiación, en ocasiones pueden llegar a tener dicho atributo, cuando entran a formar parte

${ }^{108}$ SChEPELER VÁsQuez, El delito de hurto, cit. (n. 14), pp. $46 \mathrm{~s}$.

${ }^{109}$ Véase Etcheberry, Derecho penal, cit. (n. 8), III, p. 301, quien arriba a esta conclusión sobre la base del artículo $19 \mathrm{~N}^{\circ} 2$ de la Constitución, que establece que en Chile no hay esclavos.

${ }^{110}$ Bullemore - Mackinnon, Curso, cit. (n. 8), IV: Parte especial, p. 18.

${ }^{111}$ Politoff - Matus - Ramírez, Lecciones, cit. (n. 7), p. 303. 
del comercio, como sucede, por ejemplo, con las momias en los museos ${ }^{112}$. Lo mismo ocurre con los órganos y fluidos del cuerpo. Piénsese, verbigracia, en los bancos de sangre y de semen, y en los miembros corporales que son objeto de investigación científica en centros de estudio ${ }^{113}$.

En todo caso, el hecho de que, en general, el cadáver no sea cosa susceptible de apropiación para efectos del delito de hurto o robo, no impide considerar que sí puedan ser objeto de dicho delito las ropas, joyas u otros objetos con que se le haya revestido, ya que éstos pertenecen a la sucesión del difunto, aun cuando se encuentren depositados en la tumba ${ }^{114}$. La circunstancia de que tales objetos estén en un sepulcro no permite sostener que hayan sido abandonados para que cualquier persona se los pueda apropiar, sino sólo que se encuentran en una esfera de custodia, dentro de la cual se quiere que permanezcan siempre. No impide esta conclusión la existencia del artículo $321 \mathrm{CP}$., que sanciona al que violare los sepulcros o sepulturas practicando cualquier acto que tienda directamente a faltar el respeto debido a la memoria de los muertos, porque el fin de esta disposición no es proteger la propiedad, sino los sentimientos de piedad por los difuntos, especialmente los de sus familiares y seres queridos.

\section{Cosa susceptible de apreciación pecuniaria.}

De la lectura del artículo $432 \mathrm{CP}$. no se deduce que la cosa objeto material del delito de hurto o robo deba ser susceptible de apreciación pecuniaria. Pero es obvio que debe serlo. Por lo que respecta al hurto, tal conclusión se extrae del criterio de punición empleado en los artículos 446 y 494 bis del mismo Código, los que atienden al valor de la cosa sustraída. Y en cuanto al robo ${ }^{115}$, si bien es cierto que ni en el que se ejecuta con fuerza en las cosas ni en el que se comete con violencia o intimidación en las personas el legislador atiende al valor de la cosa apropiada para determinar la pena aplicable, la conclusión debe ser la misma. En efecto, tanto en una como en otra clase de robo, debe existir antijuridicidad material del comportamiento, lo que exige una afectación de bienes jurídicos, dentro de los cuales se encuentran la propiedad, la posesión y la mera tenencia, entendidas como una relación patrimonial

${ }^{112}$ Así, Muñoz Conde, Derecho penal, cit. (n. 36), p. 373.

${ }^{113}$ Cfr. Garrido Montt, Derecho penal, cit. (n. 5), IV, p. 166, quien considera que han ingresado al tráfico mercantil las prótesis (por ejemplo, una pierna ortopédica) y la sangre cuando ha sido envasada.

${ }^{114}$ Así, Etcheberry, Derecho penal, cit. (n. 8), III, p. 302. En contra, Schepeler VÁsQuez, El delito de hurto, cit. (n. 14), p. 40.

${ }^{115}$ Lo que a continuación se dice en el texto para el robo, es válido también para el hurto, por lo que debería tenerse en consideración incluso si se modificara el criterio de punición de este delito, que atiende exclusivamente al valor de la cosa hurtada. 
entre una persona y una cosa, que permite a su titular obtener un beneficio económico. En otras palabras, aunque la ley no lo diga expresamente, para poder apreciar un robo, la cosa apropiada debe tener un valor económico ${ }^{116}$. Si no lo tiene, a efectos penales sólo interesará el atentado contra otros bienes jurídicos que en un robo podrían verse afectados, como la inviolabilidad del hogar, la vida, la salud, etc., los que en caso de resultar lesionados o expuestos a un riesgo, darán lugar a un delito distinto.

De lo señalado se desprende que no basta con que la cosa sustraída tenga únicamente un valor de afección ${ }^{117}$, como sería, por ejemplo, el caso de una flor marchita que se guarda entre las páginas de un libro, como recuerdo de un amor de la adolescencia. Ni siquiera podría aceptarse que se diga que en tales casos se trate de un hurto falta, argumentando que lo único que exige el artículo 494 bis CP. es que la cosa hurtada no valga más de media unidad tributaria mensual ${ }^{118}$, ya que tal disposición señala que el valor de la cosa hurtada no debe pasar de dicha cantidad, lo que demuestra que la cosa debe tener algún valor económico.

En todo caso, se debe ser especialmente cuidadoso en esta materia, ya que a veces ciertas cosas carecen de valor económico o éste es prácticamente inexistente para la generalidad de las personas, pero sí lo tienen, además de un valor afectivo, dentro de un círculo más o menos amplio de gente. Piénsese, por ejemplo, en el valor que a un antiguo sello de correos usado se le da dentro de un grupo de filatelistas ${ }^{119}$.

Un punto interesante en relación con el valor económico de la cosa apropiada es el de la situación de los documentos de pago. Como es sabido, dichos documentos tienen una materialidad (papel) que, intrínsecamente considerada, es de un valor económico mínimo, como sucede, por ejemplo, con los billetes de banco, los cheques, los vales vista, etcétera. Sin embargo, se les considera como medios de pago cuyo valor pecuniario está constituido por la cantidad de dinero que en ellos aparezca en el momento de la sustrac-

${ }^{116}$ Cfr. Garrido Montt, Derecho penal, cit. (n. 5), IV, pp. 167 y 192.

${ }^{117}$ En este sentido, Politoff - Matus - Ramírez, Lecciones, cit. (n. 7), p. 304. En contra, SCHepeler VÁsQuez, El delito de hurto, cit. (n. 14), p. 20.

${ }^{118}$ Con una argumentación de esta clase, una opinión minoritaria en España plantea que es posible el hurto de una cosa que sólo tenga valor afectivo, y que se castiga como falta. Así, Zugaldía Espinar, Los delitos contra la propiedad y el patrimonio, cit. (n. 26), p. 27; De la MATA BARranco, Norberto, Tutela penal de la propiedady delitos de apropiación. El dinero como objeto material de los delitos de hurto y apropiación indebida (Barcelona, PPU, 1994), p. 204. La mayoría, en cambio, excluye las cosas con un valor puramente afectivo. Por todos: González Rus, Delitos contra el patrimonio, cit. (n. 69), p. 457.

${ }^{119}$ Etcheberry, Derecho penal, cit. (n. 8), III, p. 307. 
ción, valor que es adquirido por el sujeto activo junto con la apropiación del documento.

En consecuencia, si el sujeto se apropia de diez billetes de diez mil pesos, cada uno de los cuales tiene una materialidad que cuesta sólo diez pesos, no comete un hurto de una cosa que vale cien pesos, sino uno de una cosa que vale cien mil pesos. Del mismo modo, si se apropia de un cheque que se encuentra girado al portador por una suma de quinientos mil pesos, teniendo el papel en que consta un valor de trescientos pesos, no hurta una cosa que vale trescientos pesos, sino una que vale quinientos mil pesos. En ambos casos, el sujeto se hace de un medio de pago que puede, sin más, utilizar en el mercado (en el primero, de cien mil pesos, con que puede adquirir bienes o servicios; en el segundo, de quinientos mil pesos, con que también puede realizar una adquisición o cobrar el documento).

Pero si en nuestro ejemplo el cheque del que se apropia el agente se encuentra con todas sus menciones en blanco -como muchas veces sucede en la práctica-, el hurto es de una cosa que sólo vale trescientos pesos (el costo del papel), ya que no se hace de un medio de pago que pueda utilizar sin más en el mercado. Para poder usarlo en la adquisición de bienes o servicios o en su cobro necesita llenar sus menciones, lo que puede configurar un delito de estafa. Lo mismo ocurre si lo apropiado es un talonario de cheques en blanco ${ }^{120} \mathrm{o}$ un cheque nominativo (que sólo puede ser cobrado por su beneficiario). Por eso, bien cabría la posibilidad de aplicar en estos casos el principio de insignificancia, como criterio excluyente de la imputación objetiva del comportamiento a efectos del hurto, sin perjuicio de la eventual responsabilidad por el posterior delito de estafa ${ }^{121}$.

En síntesis, como afirma Garrido Montt, "lo decisivo [...] en estos casos, es si el valor que representa el título es o no adquirido por el delincuente conjuntamente con su apoderamiento" 122 .

Por la misma razón, cuando se trata de documentos que permiten a quien los porta adquirir algún bien o servicio, su valor pecuniario es el del bien o servicio a que dan derecho, no el de su materialidad. Es lo que ocurre, por

${ }^{120}$ En este sentido, puede verse la sentencia del Tribunal Supremo español, de fecha 14 de mayo de 1989, citada por García Arán Delitos contra el patrimonio, cit. (n. 36), p. 628.

${ }^{121}$ Así, Robles Planas, Delitos contra el patrimonio, cit. (n. 69), p. 187. De hecho, el Tribunal Supremo español ha sostenido esta tesis en sus sentencias de fechas 23 de febrero de 2001, 8 de julio de 2004 y 29 de mayo de 2006, citadas por Queralt JiméNEZ, Derecho penal, cit. (n. 36), p. 381.

${ }^{122}$ Garrido Montt, Derecho penal, cit. (n. 5), IV, p. 163. Similar, Politoff Matus - Ramírez, Lecciones, cit. (n. 7), p. 305. 
ejemplo, con las entradas para asistir al cine, los billetes para viajar en avión, etcétera $^{123}$.

Otro punto, vinculado con el anterior, es el relativo a la situación de los billetes de lotería o de otros juegos de azar. La doctrina suele efectuar a este respecto un distingo, según si el billete resulta en definitiva premiado o no: si así ocurre, el valor de la cosa hurtada es el del monto del premio; si no sucede así, el valor es el del billete (lo que costó su adquisición) ${ }^{124}$. Como se puede advertir, se parte de la premisa de que la conducta tiene lugar antes de que se realice el sorteo. Si la acción se ejecuta después de que se sabe que el objeto a ser apropiado es el billete premiado, hay claridad en que el valor de la cosa hurtada no puede ser otro que el monto del premio ${ }^{125}$.

Según nuestra opinión, este planteamiento no puede aceptarse, ya que la solución del problema se hace depender del azar. No es de recibo que el valor de la cosa hurtada se determine por una circunstancia fortuita que pueda ocurrir con posterioridad al momento en que se ejecutó la acción, de lo cual puede depender la calificación del hecho como simple delito o como falta, con las importantes consecuencias prácticas que ello tiene. Si la conducta se realiza cuando aún no tiene lugar el sorteo, el valor de la cosa apropiada no puede ser otro que el costo del billete, pues en él va incorporada toda la expectativa del premio. El hecho de que en definitiva aquél resulte premiado sólo podría tomarse en cuenta para efectos de la responsabilidad civil ${ }^{126}$, y eventualmente en la determinación de la cuantía exacta de la pena, conforme al criterio de la mayor o menor extensión del mal producido por el delito (artículo 69 CP.).

En otro orden de ideas, como cualquier otro elemento del delito, el hecho de que la cosa apropiada sea susceptible de apreciación pecuniaria debe ser acreditado en el proceso. Ello, no sólo cuando se trata de un hurto, cuya sanción depende precisamente de cuál sea el valor de la cosa sustraída, sino también en el robo, por las razones de antijuridicidad material expuestas más arriba.

A propósito de este punto, debe tenerse presente que en nuestro sistema económico, en general, es el mercado el que determina el valor de las cosas. En consecuencia, es este valor, al que se llega por el juego de las leyes de oferta y demanda, el que debe ser probado en el proceso penal por hurto o

${ }^{123}$ GARCía ArÁn, El delito de hurto, cit. (n. 52), p. 100.

${ }^{124}$ Cfr. Muñoz Conde, Derecho penal, cit. (n. 36), p. 376, quien se muestra crítico con esta forma de solucionar el problema planteado.

${ }^{125}$ Así, García Arán, El delito de hurto, cit. (n. 52), p. 101.

${ }^{126}$ Robles Planas, Delitos contra el patrimonio, cit. (n. 69), p. 187, quien cita, en este sentido, una sentencia de la Audiencia Provincial de Almería, de fecha 26 de febrero de 2003 (ponente Martínez Ruiz). 
por robo ${ }^{127}$. El valor que la cosa tenía cuando fue apropiada, no el que tiene cuando el proceso se lleva a cabo.

Normalmente, cuando se trata de la apropiación de cosas que se encuentran a la venta en establecimientos comerciales, su precio de venta corresponde, más o menos, al del valor de la cosa, incluso considerando que entre los diversos establecimientos puede haber diferencias de precio. Sin embargo, no siempre existe dicha correspondencia, ya que a veces se colocan objetos a la venta muy por debajo de su precio de mercado (por ejemplo, para sacar del mercado a algún competidor) o, a la inversa, a un precio muy superior al de mercado. En estos casos, el precio de venta de la cosa no coincide con el valor que el mercado le asigna, lo que en sistemas que, como el nuestro, establecen la sanción del hurto en función del valor de la cosa sustraída, implica que la determinación de la pena queda en buena medida entregada a la víctima ${ }^{128}$. Por eso no resulta aconsejable que el legislador establezca en materia de hurto o robo una regla absoluta que considere, como valor de la cosa hurtada o robada, su precio de venta, tal como ocurre, por ejemplo, en el artículo 365, párrafo segundo, de la Ley de Enjuiciamiento Criminal española ${ }^{129}$. En este sentido, parece más razonable lo dispuesto en el inciso tercero del artículo 390 de nuestro Código Procesal Penal, que tras señalar que si un hurto falta se comete en un establecimiento de comercio, para determinar el valor de la cosa se considerará su precio de venta, agrega la siguiente frase: "salvo que los antecedentes que se reúnan permitan formarse una convicción diferente". Nos parece que esto hace posible prescindir del precio de venta de la cosa, precisamente, cuando éste difiere del valor de mercado.

\section{BibLIOGRAFÍA}

Aguilar Aranela, Cristian, Delitos patrimoniales (Santiago, Editorial Metropolitana, 2008).

Alessandri Rodríguez, Arturo, Similitud del concepto de cosa mueble en el derecho civily en el derecho penal, en Revista de Ciencias Penales, 2a época, 8 (1945).

Bajo Fernández, Miguel, Ánimo de lucro y ánimo de hacerse pago, en Revista de Derecho Público, 2a época, año 11, 1 (Madrid, 1976).

${ }^{127}$ Politoff - Matus - Ramírez, Lecciones, cit. (n. 7), p. 304.

${ }^{128}$ Así, cfr. entrevista a Medina Jara, Rodrigo, en Debate genera aumento de penas para 'hurto hormiga, en La Semana Jurídica, 189 (semana del 21 al 27 de junio de 2004), p. 4.

${ }^{129}$ Véase la crítica de Serrano Gómez - Serrano Maíllo, Derecho penal, cit. (n. 24), p. 354. En todo caso, en España, la sanción del hurto no se hace depender del valor de la cosa sustraída, aunque sí depende de ello la calificación del hecho como delito o como falta, en función de si excede o no de cuatrocientos euros, respectivamente. 
Bascuñán Rodríguez, Antonio, Delitos contra intereses instrumentales, en Revista de Derecho de la Universidad Adolfo Ibánez, 1 (2004).

BAscuñán Rodríguez, Antonio, El robo como coacción, en Revista de Estudios de la Justicia, 1 (Centro de Estudios de la Justicia, Facultad de Derecho, Universidad de Chile, 2002).

Bello, Andrés - Cuervo, Rufino, Gramática de la lengua castellana (Buenos Aires, Editorial Spena Argentina, 1945).

BINDER, Alberto, Introducción al derecho procesal penal (2a edición, Buenos Aires, Ad Hoc, 2004).

Blasco Fernández de Moreda, Francisco, Hurto, en Enciclopedia Jurídica Omeba (Buenos Aires, Editorial Bibliográfica Argentina, 1961), XIV.

Bullemore, Vivian - Mackinnon, John, Curso de Derecho penal (2ª edición, Santiago, LexisNexis, 2007), IV: Parte especial.

Carrara, Francesco, Programa de Derecho criminal. Parte especial (trad. Ortega Torres - Guerrero, Bogotá, Temis, 1959), IV.

Claro Solar, Luis, Las sustracciones de electricidad ante la ley penal, en Revista de Derecho y Jurisprudencia, 25 (julio-agosto 1928) 5-6.

Совo del Rosal, Manuel - Vives Antón, Tomás, Derecho penal. Parte general (5 ${ }^{\mathrm{a}}$ edición, Valencia, Tirant lo Blanch, 1999).

Cuello Calón, Eugenio, Derecho penal. Parte especial (9a edición, Barcelona, 1955), II.

De la Mata Barranco, Norberto, Tutela penal de la propiedad y delitos de apropiación. El dinero como objeto material de los delitos de hurto y apropiación indebida (Barcelona, PPU, 1994).

De Rivacoba y Rivacoba, Manuel (dir.), Código Penal de la República de Chile y Actas de las Sesiones de la Comisión Redactora del Código Penal chileno (Valparaíso, Edeval, 1974).

De Vicente Martínez, Rosario, El delito de robo y hurto de uso de vehículos (Valencia, Tirant lo Blanch, 2007).

Del Río, Raimundo, Derecho penal (Santiago, Editorial Nascimento, 1935), III.

Etcheberry, Alfredo, Derecho penal. Parte especial (3 $3^{\text {a }}$ edición, Santiago, Editorial Jurídica de Chile, 1998), III..

García Arán, Mercedes, El delito de hurto (Valencia, Tirant lo Blanch, 1998).

García Arán, Mercedes, Delitos contra el patrimonio y contra el orden socioeconómico, en Córdoba Roda - García Arán (directores), Comentarios al Código Penal. Parte especial (Madrid, Marcial Pons, 2004), I.

García Carvajal, Edmundo, El hurto de uso (Santiago, Editorial Universitaria, 1962).

Garrido Montt, Mario, Derecho penal. Parte especial (4a edición, Santiago, Editorial Jurídica de Chile, 2008), IV.

GonZÁlez Rus, Juan José, Delitos contra el patrimonio y contra el orden socioeconómico, en CоBo DEl Rosal (coordinador), Derechopenal español. Parte especial (2a edición, Madrid, Dykinson, 2005).

Guzmán Dálbora, José Luis, El hurto de energía eléctrica, en El mismo, Estudios y defensas penales ( $3^{a}$ edición, Santiago, Legal Publishing, 2009).

KünSEMÜller, Carlos, Hurto - hurto de uso. Jurisprudencia comentada, en Temas de Derecho, Revista de la Universidad Gabriela Mistral, año XIII, 1 y 2 (1998). 
Labatut Glena, Gustavo, Derecho penal (7a edición actualizada por Julio Zenteno Vargas, Santiago, Editorial Jurídica de Chile, 2000), II.

Mantilla Jacome, Rodolfo, Hurto de uso, en Derecho penal y Criminología. Revista del Instituto de Ciencias Penales y Criminológicas de la Universidad Externado de Colombia, 7 (1984) 23.

Mañalich Raffo, Juan Pablo, Autotutela del acreedor y protección penal del deudor. $L$ a realización arbitraria del propio derecho frente a los delitos contra la libertad, la propiedad y el patrimonio (Santiago, Ediciones Jurídicas de Santiago, 2009).

Medina JARA, Rodrigo, entrevista en Debate genera aumento de penas para hurto hormiga, en La Semana Jurídica, 189 (semana del 21 al 27 de junio de 2004).

Mera Figueroa, Jorge, Animo de lucro en el hurto. Comentario a sentencia de la Corte de Apelaciones de Concepción de 20 de enero de 1970, en Revista de Ciencias Penales,

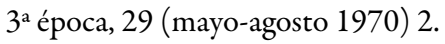

Mir Puig, Santiago, Derecho penal. Parte general ( $7^{\mathrm{a}}$ edición, Buenos Aires - Montevideo, B de F, 2004).

Muñoz Conde, Francisco, Derecho penal. Parte especial (6a edición, Valencia, Tirant lo Blanch, 2007).

Politoff Lifschitz, Sergio, El delito de apropiación indebida (Santiago, Editorial Jurídica ConoSur, 1992).

Politoff, Sergio - Matus, Jean Pierre - Ramírez, María Cecilia, Lecciones de Derecho penal chileno. Parte especial ( $2^{a}$ edición, Santiago, Editorial Jurídica de Chile, 2005).

Queralt Jiménez, Joan, Derecho penal español. Parte especial (5ª edición, Barcelona, Atelier, 2008).

Quintero Olivares, Gonzalo, Delitos contra el patrimonio y contra el orden socioeconómico, en El mismo (director), Comentarios a la parte especial del Derecho penal (6a edición, Pamplona, Thomson-Aranzadi, 2007).

Ramos Mejías, Enrique, El hurto de uso, en El mismo, Estudios de Derecho penal (Buenos Aires, Editorial Ideas, 1947).

Revilla De Cos, Santiago, Gramática española moderna (2a edición, México, McGrawHill, 1986).

Robledo Villar, Antonio, Delitos contra el patrimonio y el orden socioeconómico. Comentarios a los artículos 234 a 289 del nuevo Código Penal (Barcelona, Bosch, 1997).

Robles Planas, Ricardo, Delitos contra el patrimonio, en Silva Sánchez (director), Ragués I VAllès (coordinador), Lecciones de Derecho penal. Parte especial (2a edición, Barcelona, Atelier, 2009).

Rodríguez Devesa, José María - Serrano Gómez, Alfonso, Derecho penal español. Parte especial (18 a edición, Madrid, Dykinson, 1995).

Rodríguez Devesa, José María, Hurto, en Nueva Enciclopedia Jurídica Seix (Barcelona, Seix, 1979), XI.

Rodríguez Ramos, Luis, El hurto de uso en general, en Cuadernos de Política Criminal, 1 (1977).

SÁnchez Moreno, José, El hurto (Barcelona, Bosch, 1999).

Sanhueza Romero, Juana, Delito de hurto y robo con fuerza en las cosas, en Revista de Derecho de la Universidad de Concepción, año LXIX, 209 (enero-junio 2001).

Schepeler VÁs lez, Enrieue, Hurto de uso. Comentario a sentencia, en Revista de Ciencias Penales, 2a época, 10 (abril-septiembre 1948) 2-3. 
SChepeler VÁseuez, Enrique, El delito de hurto. Estudio de doctrina, de jurisprudencia $y$ de legislación comparada (Santiago, 1939).

Serrano Gómez, Alfonso - Serrano Maíllo, Alfonso, Derecho penal. Parte especial (11 $1^{a}$ edición, Madrid, Dykinson, 2006).

Soto Piñeiro, Miguel, Comentario a sentencia, en Revista de Ciencias Penales, $4^{a}$ época, 29 (1987-1989) 2.

Soto Piñeiro, Miguel, El hurto del acreedor: ¿una conducta atípica? en Revista de Ciencias Sociales. Derecho y Sociedad, 3-4 (1989).

Soto Piñeiro, Miguel, La apropiación indebida (Acción, autor y resultado típico) (Santiago, Editorial Jurídica ConoSur, 1994).

Ugarte, José Manuel - Von Lapcevic, Sascha, Hurto de energía eléctrica. Sustracción, apoderamiento ilícito y fraude (Buenos Aires, Depalma, 1975).

Vodanovic Hernán, en Alessandri Rodríguez, A. - Somarriva Undurraga, M. Curso de Derecho Civil, redactado, ampliado y puesto al día por Vodanovic H. (3 ${ }^{a}$ edición, Santiago, Editorial Nascimento, 1974), II: Los bienes y los derechos reales.

Zugaldía Espinar, José Miguel, Los delitos contra la propiedad y el patrimonio (Madrid, Akal, 1988). 
